\title{
Isotopic Signatures by Bulk Analyses
}

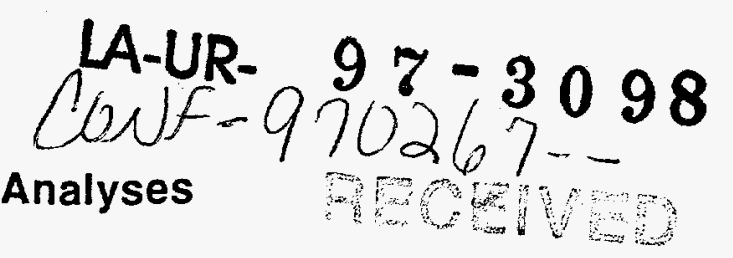

\author{
D. W. Efurd and D. J. Rokop \\ Los Alamos National Laboratory, Los Alamos, NM, USA
}

\section{Abstract}

Los Alamos National Laboratory has developed a series of measurement techniques for identification of nuclear signatures by analyzing bulk samples. Two specific applications for isotopic fingerprinting to identify the origin of anthropogenic radioactivity in bulk samples are presented. The first example is the analyses of environmental samples collected in the U.S. Arctic to determine the impact of dumping of radionuclides in this polar region. Analyses of sediment and biota samples indicate that for the areas sampled the anthropogenic radionuclide content of sediments was predominantly the result of the deposition of global fallout. No other sources of anthropogenic radionuclides could be conclusively identified in the sediments. The anthropogenic radionuclide concentrations in fish, birds and mammals were very low. Assuming that ingestion of food is an important pathway leading to human contact with radioactive contaminants and given the dietary patterns in coastal Arctic communities, it can be surmised that marine food chains are presently not significantly affected. The second example is isotopic fingerprinting of water and sediment samples from the Rocky Flats Facility (RFP). RFP is a U. S. Department of Energy facility where components were manufactured for nuclear weapons. The following conclusions are made concerning radioactivity in the water and sediment samples collected at RFP. The largest source of anthropogenic $\mathrm{Ya}$ dioactivity presently affecting surface-waters at RFP is the sediments that are currently residing in the holding ponds. One gram of sediment from a holding pond contains approximately 50 times more plutonium than 1 liter of water from the pond. Essentially $100 \%$ of the uranium in Pond $\mathrm{A}-1$ and Pond $\mathrm{A}-2$ originated as depleted uranium. The largest source of radioactivity in the terminal Ponds A-4, B-5 and C-2 was naturally occurring uranium and its decay product radium. The uranium concentrations in the waters collected from the terminal ponds contained $0.05 \%$ or less of the interim standard calculated derived concentration guide for uranium in waters available to the public. All of the radioactivity observed in soil, sediment and water samples collected at RFP was naturally occurrring, the result of processes at RFP or the result of global fallout. No extraneous anthropogenic alpha, beta or gamma activities were detected. The plutonium concentrations in Pond C-2 appear to vary seasonally.

\section{Applications}

\section{Analyses of Environmental Samples Collected in the United States Arctic Regions}

Global fallout from nuclear weapons testing in the atmosphere, discharges from nuclear facilities in the Former Soviet Union (FSU) into Siberian rivers, undersea thermonuclear explosions at the Novaya 


\section{DISCLAIMER}

This report was prepared as an account of work sponsored by an agency of the United States Government. Neither the United States Government nor any agency thereof, nor any of their employees, makes any warranty, express or implied, or assumes any legal liability or responsibility for the accuracy, completeness, or usefulness of any information, apparatus, product, or process disclosed, or represents that its use would not infringe privately owned rights. Reference herein to any specific commercial product, process, or service by trade name, trademark, manufacturer, or otherwise does not necessarily constitute or imply its endorsement, recommendation, or favoring by the United States Government or any agency thereof. The views and opinions of authors expressed herein do not necessarily state or reflect those of the United States Government or any agency thereof. 


\section{DISCLAMIER}

Portions of this document may be illegible in electronic image products. Images are produced from the best available original document. 
Zemlya test site, the Chernobyl accident, aircraft and satellite accidents involving radioactive materials, and dumping of radioactive waste in the ocean are considered as sources of radioactivity in the Arctic. There are a number - of excellent reviews documenting the release of radioactivity to the Arctic./1,2,3,4/

This study was performed to establish a quality controlled data set about the levels of radionuclide activity in the environment and selected biota in the U. S. Arctic. Samples were collected by the National Oceanic and Atmospheric Administration (NOAA), the National Biological Service, and the North Slope Borough's Department of Wildlife Management. Samples were collected in northwestern Alaska with emphasis on species harvested for subsistence in Barrow, Alaska. Biota samples of subsistence and ecological value were analyzed to search evidence of bioaccumulation and to determine the radiation exposures associated with subsistence living in northern Alaska. Sediment samples were also collected. Figure 1 shows the sampling locations selected for this study. Table 1 lists the sediment sampling locations. Table 2 lists the biota collected for this study. Complete invertebrates and fishes were analyzed. The specific tissues analyzed from the large mammals are also listed in Table 2. The samples were shipped to Los Alamos $\mathrm{Na}$ tional Laboratory (LANL) for analyses. The samples were weighed, dried and ashed. The ashed samples were analyzed by highresolution gamma ray spectroscopy. Next, the ashed samples were dissolved in strong mineral acids./5,6/
The ${ }^{240} \mathrm{Pu} /{ }^{39} \mathrm{Pu}$ atom ratios were measured by Thermal Ionization Mass Spectrometry (TIMS)./8,9/ The cesium fractions were isolated by sorption on microcrystalline ammonium phosphomolybdate./10/ The strontium fractions were isolated as carbonates and purified by a series of cation exchange chromatography steps./11/ The ${ }^{90} \mathrm{Sr}$ activity levels were determined by measuring the ${ }^{90} \mathrm{Y}$ daughter using beta counters.

Figure 1. The Sampling Locations

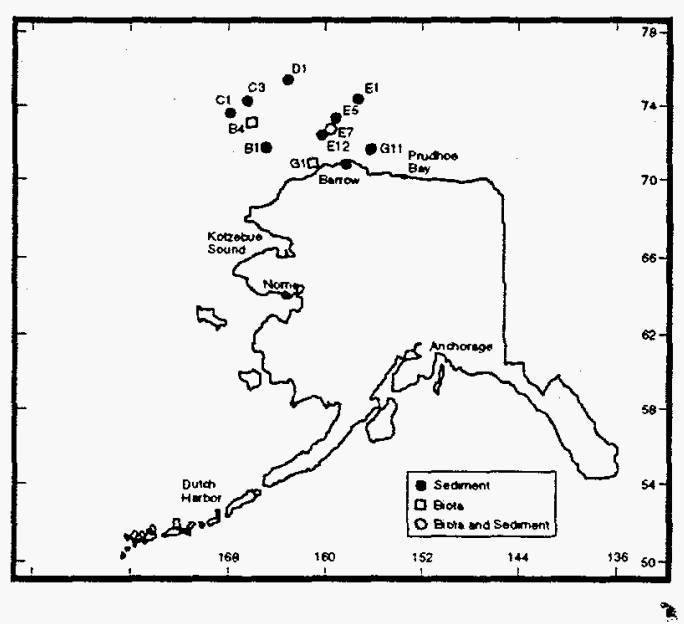

Table 1. Sediment Sampling Lọcations in the Beaufort Sea

\begin{tabular}{|c|c|c|c|}
\hline Sta. & Latitude & Longitude & $\begin{array}{l}\text { Depth } \\
\text { (m) }\end{array}$ \\
\hline E-12 & $72: 30.0 \mathrm{~N}$ & $159: 48.0 \mathrm{~W}$ & 40 \\
\hline E-07 & $72: 54.1 \mathrm{~N}$ & $158: 59.2 \mathrm{~W}$ & 113 \\
\hline $\mathrm{E}-05$ & $73: 13.3 \mathrm{~N}$ & $158: 16.9 \mathrm{~W}$ & 1976 \\
\hline E-01 & $74: 24.0 \mathrm{~N}$ & $155: 43.1 \mathrm{~W}$ & 3813 \\
\hline $\mathrm{D}-01$ & $75: 23.8 \mathrm{~N}$ & $163: 00.3 \mathrm{~W}$ & 2050 \\
\hline $\mathrm{C}-03$ & $73: 18.1 \mathrm{~N}$ & $167: 05.8 \mathrm{~W}$ & 289 \\
\hline $\mathrm{C}-01$ & $73: 53.8 \mathrm{~N}$ & $168: 29.7 \mathrm{~W}$ & 236 \\
\hline $\mathrm{B}-04$ & $73: 05.8 \mathrm{~N}$ & $166: 59.8 \mathrm{~W}$ & 52 \\
\hline $\mathrm{B}-01$ & $71: 59.7 \mathrm{~N}$ & $165: 21.2 \mathrm{~W}$ & 34 \\
\hline $\mathrm{G}-01$ & $70: 54.1 \mathrm{~N}$ & $160: 10.7 \mathrm{~W}$ & 44 \\
\hline $\mathrm{G}-11$ & $71: 54.3 \mathrm{~N}$ & $154: 46.0 \mathrm{~W}$ & 340 \\
\hline
\end{tabular}

Plutonium-239, ${ }^{240} \mathrm{Pu},{ }^{137} \mathrm{Cs}$ and ${ }^{90} \mathrm{Sr}$ were analyzed from a single aliquot of each sample. The plutonium was separated and purified by ion exchange chromatography./7/ 
Table 2. Biota Samples

\begin{tabular}{|l|l|l|l|}
\hline Species & $\begin{array}{l}\text { Wet } \\
\text { Weight } \\
(\mathbf{g})\end{array}$ & $\begin{array}{l}\text { Dry } \\
\text { Weigh } \\
\mathbf{t}(\mathbf{g})\end{array}$ & $\begin{array}{c}\text { Type } \\
\text { of Tis- } \\
\text { sue }\end{array}$ \\
\hline Sipunculids & 190.3 & 28.0 & \\
\hline Crinoids & 119.5 & 31.2 & \\
\hline Sea urchin & 1575.6 & 602.3 & \\
\hline Spider crab & 711.4 & 259.7 & \\
\hline Starfish & 409.2 & 146.5 & \\
\hline Soft starfish & 94.6 & 32.7 & \\
\hline Nudibranch & 1453.1 & 439.6 & \\
\hline Broad Whitefish & 1920.2 & 354.0 & \\
\hline Arctic Char & 230.0 & 95.0 & \\
\hline Arctic Cod & 936.0 & 487.0 & \\
\hline Arctic Cisco & 409.1 & 159.0 & \\
\hline Least Cisco & 463.0 & 134.3 & \\
\hline Chum Salmon & 3453.0 & 1204.0 & \\
\hline Dolly Varden & 1018.0 & 349.1 & \\
\hline Bowhead Whale & 826.0 & 798.5 & blubber \\
\hline Bowhead Whale & 1577.2 & 441.6 & liver \\
\hline King Eider & 688.1 & 225.6 & muscle \\
\hline Polar Bear & 1429.8 & 481.0 & muscle \\
\hline Caribou & 86.8 & 37.9 & muscle \\
\hline Caribou & 184.5 & 57.0 & liver \\
\hline Caribou & 156.7 & 38.0 & kidney \\
\hline Bearded Seal & 373.1 & 351.1 & blubber \\
\hline
\end{tabular}

Americium was separated by coprecipitation with lanthanum fluoride and by a HDEHP extraction./12/ The final purification was accomplished by anion exchange chromatography. The americium was quantified by solid state alpha spectrometry. All chemical processing and TIMS analyses are conducted in Class100 clean rooms.

The high resolution gamma ray spectroscopy measurements were obtained by placing the ashed residues in counting vials $4 \mathrm{~cm}$ o.d. $x$ $2.7 \mathrm{~cm}$ high and counting for 3000 minutes using an intrinsic germanium detector having $81 \%$ efficiency relative to a 3 " $\times 3$ " sodium iodide crystal. The resolution of the intrinsic germanium detector is $1.7 \mathrm{keV}$ Full Width Half Maximum (FWHM) at $1.33 \mathrm{MeV}$.
The americium alpha activity levels were determined by counting the samples on $300 \mathrm{~mm}^{2}$ solid state surface barrier detectors. The detectors have a resolution (FWHM $\sim 20 \mathrm{keV}$ ) and a detection efficiency of $35 \%$. The detectors had backgrounds of $0.5-1.2 \mathrm{c} / \mathrm{hr}$ in the 4-6 $\mathrm{MeV}$ range. Samples were counted for 6,000 to 10,000 minutes.

Strontium-90 was counted on low level beta counters. The detector system uses a titanium foil window that prevents sensitivity below 50 $\mathrm{keV}$. The detector chambers are fabricated from high purity copper, placed inside an active background suppression umbrella, and surrounded by a few tons of lead. The counter background averages 0.2 cpm. Propane is used as the counting gas.

The TIMS used in this study is a modified version of the $30.5-\mathrm{cm}$ radius, $90^{\circ}$ deflection, thermal ionization instrument developed at the National Bureau of Standards (now named the National Institute of Standards and Technology, or NIST)./13/ The spectrometer is equipped with a sample turret that holds five Surface Ionization Diffusion (SID) controlled filaments./14/

NIST Standard Reference Materials (SRM) for environmental radioactivity were processed concurrently as part of our quality assurance program. These SRMs served as the matrix based quality assurance standards for the sediment analyses. Table 3 lists the NIST certified matrix based reference materials that we used during this investigation. Processing blanks were also analyzed as part of our QAVC program. We also have an extensive 
QAVC program to verify that the instrument measurement systems are functioning properly.

Table 3. NIST Matrix Based QAVQC Samples

\begin{tabular}{|l|l|}
\hline SRM 4350B & Columbia River Sediment \\
\hline SRM 4353 & Rocky Flats Soil Number 1 \\
\hline SRM 4354 & Freshwater Lake Sediment \\
\hline SRM 4355 & Peruvian Soil \\
\hline
\end{tabular}

Each gamma counting system has one or more standards that are counted each day./15/ Those data are computer processed to check energy calibration, energy resolution and overall detection efficiency. These data are archived as well as being plotted on running plots that are updated weekly for reference. Absolute detection efficiency checks are made whenever any out-ofnormal incident occurs. Background counts are made whenever there are no samples being counted. The background data were also analyzed to test for possible counter contamination.

Americium samples submitted for alpha analyses are traced with ultra pure ${ }^{243} \mathrm{Am}$. The ${ }^{243} \mathrm{Am}$ tracer is calibrated by stippling weighed amounts of the tracer on counting planchets and counting the samples on alpha detectors that have been calibrated for efficiency with standards traceable to NIST. The purity of the ${ }^{243} \mathrm{Am}$ tracer was verified by alpha spectrometry analyses. The energy calibration of the alpha spectrometers was done using a multipeak alpha standard. The proper operation of the low-level beta counter was verified by analyzing ${ }^{90} \mathrm{Sr},{ }^{90} \mathrm{Y}$ and ${ }^{137} \mathrm{Cs}$ samples traceable to NIST standards.
The TIMS was calibrated using actinide standards certified by NIST, New Brunswick Laboratory and the Commission of the European Communities - Joint Research Centre Institute for Reference Materials and Measurements (IRMM). The proper operation of the TIMS was verified by measuring Certified Reference Materials, CRM U500, CRM-128 and CBNM 072-7. The ${ }^{242} \mathrm{Pu}$ isotope dilution tracer used for TIMS analyses is standardized to gravimetrically prepared dilutions of SRM $949 f$ plutonium.

The results for the sediments and biota samples are reported in $\mathrm{Ta}$ bles 4 and 5 . Uncertainties are 1 sigma values derived from counting statistics of both the sample and background. Upper limits are values at which a distinct signal above background can be claimed with 95\% confidence.

Table 4 provides information about the origins of the radionuclides detected in the Beaufort Sea sediments. It appears that the plutonitum in the sediments originated as global fallout. The average ${ }^{240+239} \mathrm{Pu}$ atom ratio measured in the Beaufort Sea sediments was $0.19 \pm 0.02$. Krey et al. measured the ${ }^{240+239} \mathrm{Pu}$ atom ratio in global fallout to be 0.176 with a standard deviation of 0.014 and ranges from 0.12 to 0.21 around the world./16/ They measured the ${ }^{240} \mathrm{Pu} /{ }^{239} \mathrm{Pu}$ atom ratio in a soil sample collected at Barrow to be $0.18 . / 16 /$ There is no evidence of weapons grade plutonium in the sediments. The ${ }^{240} \mathrm{Pu} /{ }^{239} \mathrm{Pu}$ atom ratios in samples collected at the $\mathrm{Ne}$ vada Test Site and Semipalatinsk Nuclear Test Site range from 0.03$0.07 . / 17,18 /$ 
Table 4. Radioactivity Detected In Sediment Samples

\begin{tabular}{|c|c|c|c|c|c|c|c|c|}
\hline & $\begin{array}{l}{ }^{80} \mathrm{Sr} \\
\mathrm{Bq} / \mathrm{kg}\end{array}$ & $\begin{array}{l}{ }^{137} \mathrm{Cs} \\
\mathrm{Bg} / \mathrm{kg}\end{array}$ & $\begin{array}{c}{ }^{40} \mathrm{~K} \\
\mathrm{Bg} / \mathrm{kg}\end{array}$ & $\begin{array}{c}{ }^{212} \mathrm{~Pb} \\
\mathrm{Bg} / \mathrm{kg} \\
\end{array}$ & $\begin{array}{c}214 \mathrm{~Pb} \\
\mathrm{~Bq} / \mathrm{kg} \\
\end{array}$ & $\begin{array}{c}239+210 \mathrm{Pu} \\
\mathrm{Bg} / \mathrm{kg}\end{array}$ & $\begin{array}{l}{ }^{240} \mathrm{Pu} /^{230} \mathrm{Pu} \\
\text { Atom Ratio }\end{array}$ & $\begin{array}{l}2 \pi \mathrm{Am} \\
\mathrm{Bg} / \mathrm{kg}\end{array}$ \\
\hline$\overline{E 12}$ & $\leq 0.6$ & $6.1 \pm 2.3$ & $590 \pm 41$ & $33.8 \pm 3.7$ & $24.2 \pm 3.6$ & $0.27 \pm 0.02$ & $0.20 \pm 0.02$ & $0.10 \pm 0.01$ \\
\hline C1 & $\leq 0.7$ & $\leq 2$ & $671 \pm 16$ & $41.0 \pm 2.5$ & $16.7 \pm 2.0$ & $0.05 \pm 0.02$ & $0.20 \pm 0.07$ & $\leq 0.1$ \\
\hline E7 & $\leq 1.2$ & $11.4 \pm 2.3$ & $585 \pm 41$ & $43.9 \pm 3.9$ & $13.7 \pm 3.4$ & $0.52 \pm 0.5$ & $0.18 \pm 0.02$ & NM \\
\hline$\overline{E 1}$ & $\leq 0.6$ & $\leq 3$ & $888 \pm 36$ & $62.0 \pm 3.1$ & $62.3 \pm 4.4$ & $\leq 0.03$ & $0.18 \pm 0.05$ & $\leq 0.1$ \\
\hline$\overline{E 5}$ & $0.6 \pm 0.3$ & $8.2 \pm 2.1$ & $698 \pm 35$ & $41.3 \pm 3.7$ & $39.3 \pm 3.9$ & $\leq 0.14$ & $0.19 \pm 0.05$ & $\leq 0.3$ \\
\hline $\mathrm{CB}$ & $\leq 0.7$ & $\leq 4$ & $699 \pm 42$ & $57.0 \pm 4.0$ & $93.3 \pm 5.6$ & $0.06 \pm 0.01$ & $0.19 \pm 0.02$ & $\leq 0.1$ \\
\hline$\overline{B 1}$ & $\leq 0.7$ & $\leq 3$ & $452 \pm 27$ & $22.3 \pm 2.9$ & $19.8 \pm 2.8$ & $0.14 \pm 0.02$ & $0.17 \pm 0.04$ & $0.07 \pm 0.01$ \\
\hline G11 & $\leq 1.2$ & $7.7 \pm 1.5$ & $500 \pm 30$ & $43.0 \pm 2.6$ & $21.5 \pm 2.6$ & $0.27 \pm 0.02$ & $0.18 \pm 0.02$ & $\leq 0.3$ \\
\hline$\overline{\mathrm{D} 1}$ & $\leq 0.5$ & $3.1 \pm 1.1$ & $524 \pm 21$ & $44.1 \pm 2.2$ & $59.5 \pm 3.6$ & $\leq 0.2$ & $0.19 \pm 0.04$ & $0.06 \pm 0.01$ \\
\hline$\overline{\mathrm{B} 4}$ & $0.2 \pm 0.1$ & $5.3 \pm 1.8$ & $567 \pm 28$ & $44.7 \pm 3.6$ & $22.6 \pm 2.7$ & $0.34 \pm 0.03$ & $0.18 \pm 0.02$ & $0.11 \pm 0.01$ \\
\hline
\end{tabular}

Table 5. Radioactivity Detected in Biota Samples

\begin{tabular}{|l|l|l|l|l|l|l|l|}
\hline Sample ID & $\begin{array}{l}{ }^{80} \mathrm{Sr} \\
\mathrm{Bq} / \mathrm{kg}\end{array}$ & $\begin{array}{l}{ }^{37} \mathrm{Cs} \\
\mathrm{Bq} / \mathrm{kg}\end{array}$ & $\begin{array}{l}{ }^{70} \mathrm{~K} \\
\mathrm{~Bq} / \mathrm{kg}\end{array}$ & $\begin{array}{l}\text { 212 } \mathrm{Pb} \\
\mathrm{Bq} / \mathrm{kg}\end{array}$ & $\begin{array}{l}\text { 11/4 } \mathrm{Pb} \\
\mathrm{Bq} / \mathrm{kg}\end{array}$ & $\begin{array}{l}{ }^{239+210} \mathrm{Pu} \\
\mathrm{Bq} / \mathrm{kg}\end{array}$ & $\begin{array}{l}{ }^{21} \mathrm{Am} \\
\mathrm{Bq} / \mathrm{kg}\end{array}$ \\
\hline Sipunculids & $\leq 1.0$ & $\leq 1.0$ & $309 \pm 6$ & $10.4 \pm 0.9$ & $5.9 \pm 0.8$ & $\leq 0.03$ & $\leq 0.08$ \\
\hline Crinoids & $\leq 0.9$ & $\leq 0.8$ & $201 \pm 4$ & $\leq 0.6$ & $\leq 0.9$ & $0.08 \pm 0.02$ & $\leq 0.06$ \\
\hline Sea Urchins & $\leq 0.6$ & $\leq 2.2$ & $182 \pm 20$ & $5.6 \pm 2.1$ & $\leq 2.4$ & $\leq 0.02$ & $\leq 0.02$ \\
\hline Spider Crab & $\leq 0.3$ & $\leq 0.8$ & $209 \pm 25$ & $2.5 \pm 1.8$ & $4.5 \pm 0.7$ & $0.02 \pm 0.01$ & $\leq 0.02$ \\
\hline Reg. Starfish & $\leq 0.5$ & $\leq 1.2$ & $265 \pm 8$ & $9.9 \pm 1.2$ & $6.6 \pm 1.1$ & $\leq 0.08$ & $\leq 0.02$ \\
\hline Soft Starfish & $\leq 0.9$ & $\leq 0.8$ & $243 \pm 5$ & $3.9 \pm 0.7$ & $3.2 \pm 0.6$ & $\leq 0.01$ & $\leq 0.5$ \\
\hline Nudibranchs & $\leq 0.4$ & $\leq 2.0$ & $272 \pm 19$ & $\leq 2.5$ & $4.3 \pm 1.1$ & $\leq 0.01$ & $\leq 0.2$ \\
\hline Broad Whitefish & $0.6 \pm 0.3$ & $0.3 \pm 0.1$ & $299 \pm 21$ & $2.1 \pm 0.3$ & $\leq 1.7$ & $\leq 0.0003$ & $\leq 0.005$ \\
\hline Arctic Char & $0.3 \pm 0.2$ & $\leq 0.1$ & $323 \pm 19$ & $\leq 1.9$ & $\leq 0.9$ & $\leq 0.002$ & $\leq 0.01$ \\
\hline Arctic Cod & $\leq 0.1$ & $2.6 \pm 0.1$ & $307 \pm 12$ & $\leq 1.7$ & $\leq 0.9$ & $\leq 0.0005$ & $\leq 0.001$ \\
\hline Arctic Cisco & $1.2 \pm 0.6$ & $2.9 \pm 0.2$ & $294 \pm 29$ & $\leq 1.8$ & $\leq 2.2$ & $\leq 0.0005$ & $\leq 0.009$ \\
\hline Least Cisco & $1.5 \pm 0.4$ & $0.9 \pm 0.3$ & $319 \pm 26$ & $\leq 1.9$ & $\leq 2.4$ & $\leq 0.001$ & $\leq 0.01$ \\
\hline Chum Salmon & $\leq 0.1$ & $0.3 \pm 0.0$ & $341 \pm 19$ & $\leq 1.4$ & $\leq 1.0$ & $\leq 0.0001$ & $\leq 0.005$ \\
\hline Dolly Varden & $0.4 \pm 0.1$ & $0.5 \pm 0.2$ & $335 \pm 28$ & $\leq 2.0$ & $\leq 2.5$ & $\leq 0.0008$ & $\leq 0.006$ \\
\hline $\begin{array}{l}\text { Bowhead Whale } \\
\text { blubber }\end{array}$ & $\leq 0.008$ & $\leq 0.08$ & $15 \pm 2$ & $0.3 \pm 0.1$ & $\leq 0.08$ & $\leq 0.003$ & $\leq 0.0006$ \\
\hline $\begin{array}{l}\text { Bowhead Whale } \\
\text { liver }\end{array}$ & $0.05 \pm 0.01$ & $0.4 \pm 0.1$ & $223 \pm 5$ & $0.5 \pm 0.2$ & $0.5 \pm 0.3$ & $\leq 0.001$ & $\leq 0.004$ \\
\hline King Eider muscle & $0.05 \pm 0.02$ & $\leq 0.4$ & $305 \pm 6$ & $\leq 0.5$ & $\leq 0.4$ & $\mathrm{~N} / \mathrm{M}$ & $\mathrm{N} / \mathrm{M}$ \\
\hline Polar Bear & $\mathrm{N} / \mathrm{M}$ & $0.5 \pm 0.4$ & $339 \pm 41$ & $\leq 0.7$ & $\leq 0.8$ & $\leq 0.0005$ & $\leq 0.005$ \\
\hline Caribou muscle & $\mathrm{N} / \mathrm{M}$ & $24.3 \pm 2.9$ & $355 \pm 39$ & $\leq 0.9$ & $\leq 0.7$ & $\mathrm{~N} / \mathrm{M}$ & $\mathrm{N} / \mathrm{M}$ \\
\hline Caribou liver & $\mathrm{N} / \mathrm{M}$ & $26.7 \pm 2.8$ & $321 \pm 49$ & $\leq 1.3$ & $\leq 0.9$ & $\leq 0.001$ & $\leq 0.001$ \\
\hline Caribou kidney & $\mathrm{N} / \mathrm{M}$ & $36.2 \pm 5.4$ & $339 \pm 42$ & $\leq 1.1$ & $\leq 1.1$ & $\mathrm{~N} / \mathrm{M}$ & $\mathrm{NM}$ \\
\hline $\begin{array}{l}\text { Bearded Seal } \\
\text { blubber }\end{array}$ & $\leq 0.02$ & $\leq 0.2$ & $\leq 10$ & $\leq 0.3$ & $\leq 0.3$ & $\leq 0.005$ & $\leq 0.004$ \\
\hline
\end{tabular}

The ${ }^{240} \mathrm{Pu} /{ }^{239} \mathrm{Pu}$ atom ratio in soil samples collected adjacent to the Rocky Flats Facility was -0.06 . $/ 19,20 /$ The ${ }^{240} \mathrm{Pu} /{ }^{39} \mathrm{Pu}$ atom ratio in a spent fuel having a burn-up of 44,400 Mega Watt Days/Ton (MWD/T) was measured to be 0.55 ; hence, there is no evidence of plutonium that is associated with the processing of high- burn-up spent-fuel dissolver solutions./21/ The average ratio of ${ }^{241} \mathrm{Am}$ to ${ }^{239+240} \mathrm{Pu}$ alpha activity ratio in these sediments was $0.48 \pm 0.23$. This value is not statistically different than the ${ }^{241} \mathrm{Am} p^{239+240} \mathrm{Pu}$ alpha activity ratio of 0.33 that is present in global fallout. 
The cesium data are somewhat more difficult to interpret. Both ${ }^{239+240} \mathrm{Pu}$ and ${ }^{137} \mathrm{Cs}$ were detected in sédiment samples E7, E12, 1B, G11 and B4. The average ${ }^{239+240} \mathrm{Pu} /{ }^{137} \mathrm{Cs}$ activity ratio of these sediment samples is $0.05 \pm 0.02$. This value could be interpreted to indicate that there was a secondary source of ${ }^{137} \mathrm{Cs}$ in addition to global fallout.

However, the average ${ }^{239+240} \mathrm{Pu} /{ }^{137} \mathrm{Cs}$ activity ratio measured in the sediment samples cannot be used to conclusively prove that a second source of ${ }^{137} \mathrm{Cs}$ is present because the $0.05 \pm 0.02$ ratio measured in this study is not significantly different than the $\sim 0.07{ }^{239+240} \mathrm{Pu} /{ }^{137} \mathrm{Cs}$ ratio that is representative of present day global fallout. Review of the cesium data leads the authors to conclude that the major source of ${ }^{137} \mathrm{Cs}$ in the Beaufort Sea sediments is global fallout. The ${ }^{90} \mathrm{Sr}$ concentrations appear to be lower than the ${ }^{137} \mathrm{Cs}$ concentrations. The amount of ${ }^{90} \mathrm{Sr}$ relative to ${ }^{137} \mathrm{Cs}$ and ${ }^{239+240} \mathrm{Pu}$ in the samples is depleted relative to global fallout.

Little anthropogenic radioactivity was detected in the biota samples. Cesium-137 and ${ }^{90} \mathrm{Sr}$ were the radionuclides most often detected in the biota samples. Observed levels of radioactivity in animals and tissues are much lower than the screening value for human food according to U. S. Food and Drug Administration regulations. For example, the screening limit for ${ }^{137} \mathrm{Cs}$ is $370 \mathrm{~Bq} / \mathrm{kg}$.

The anthropogenic radionuclide content of sediments collected in the Beaufort Sea was predominantly the result of the deposition of global fallout. No other sources of anthro- pogenic radionuclides could be conclusively identified in the sediments. The anthropogenic radionuclide concentrations in fish, birds and mammals were very low. Assuming that ingestion of food is an important pathway leading to human contact with radioactive contaminants and given the dietary patterns in coastal Arctic communities, it can be surmised that marine food chains are presently not significantly affected.

Characterization of the Radioactivity in Surface-Waters Collected On Site at the Rocky Flats Facility

The Rocky Flats Plant (RFP) is a Department of Energy (DOE) facility where plutonium and uranium components were manufactured for nuclear weapons. During plant operations radioactivity was inadvertently released into the environment. Plutonium has been detected in air, soil and water samples at RFP. The largest single contributor to plutonium in the environment is resuspension of contaminants originating at the OU2/903 Pad./22/ Between January and June 1968 oil drums containing cutting oil contaminated with plutonium were removed from the OU2/903 Pad. Some of the drums leaked and high winds spread the plutonium. Seed, et al. estimated that 6.1 $\mathrm{Ci}$ of plutonium were lost to the soil./23/ Uranium releases have also occurred. The amount of uranium released by RFP has not been studied as thoroughly as the plutonium releases. Actinides may be introduced into surface-waters at RFP by inadvertent release of contaminated fluids from the plant site, wind deposition of contaminated soil and erosion of top- 
soil by rain and snow melt. This study was initiated to characterize the radioactivity present in surface-waters at RFP. The naturally occurring and anthropogenic radioactivities were measured in water, sediment and soil samples.

Figures 2 and 3 illustrate the creeks, diversion ditches, ponds and reservoirs in the RFP vicinity. Their functions are described below. Three drainage basins and natural ephemeral streams transverse RFP. The Woman Creek drainage basin traverses and drains the southern portion of the site. The Rock Creek drainage basin drains the northwestern portion of the plant complex. The Walnut Creek drainage basin traverses the western, northern, and northeastern portions of the RFP site. Three ephemeral streams are tributary to Walnut Creek. The streams are Dry Creek, North Walnut Creek and South Walnut Creek. Figure 2 gives a schematic representation of the surface-water systems at RFP. Dams, detention ponds, diversion structures, and ditches have been constructed at RFP to control the release of plant discharges and surface (storm water) runoff. The ponds located downstream of the plant complex on North Walnut Creek are designated A-1 through A-4. Ponds on South Walnut Creek are designated B-1 through B5 . The ponds in the Woman Creek drainage basin are designated $\mathrm{C}-1$ and $\mathrm{C}-2$. Ponds $\mathrm{A}-1$ and $\mathrm{A}-2$ were constructed during the early days of plant operation. These ponds are currently used to collect seep and culvert flows and precipitation runoff from the northern area of the plant site. Ponds $A-1$ and A-2 are now being operated as non-
Figure 2. Rocky Flats Vicinity

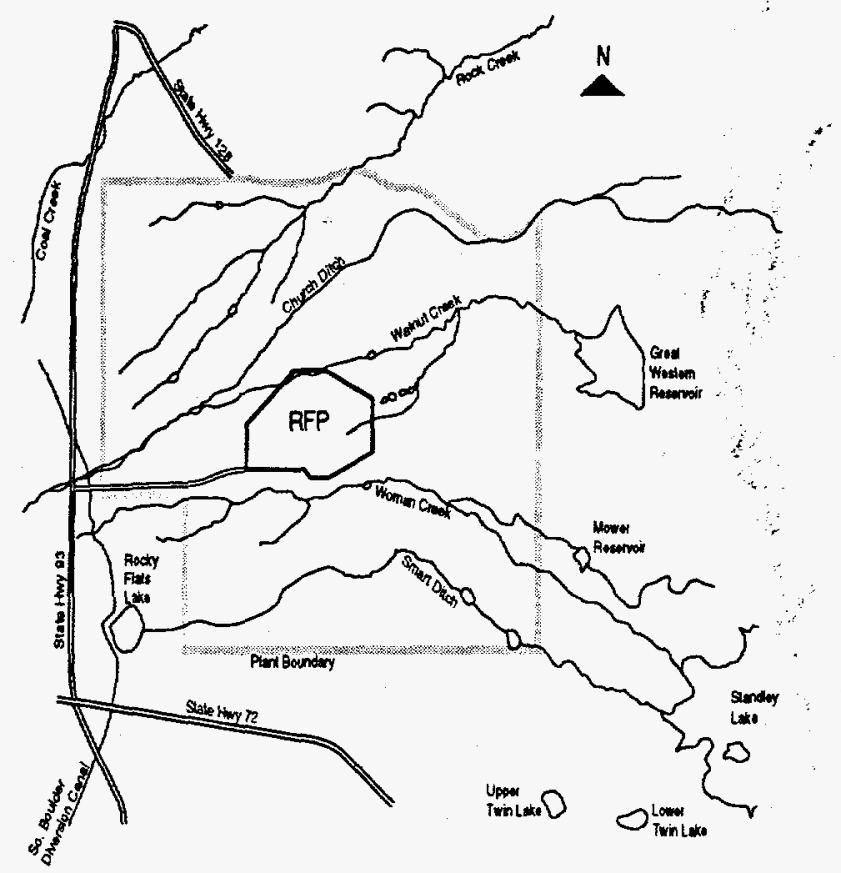

Figure 3. Schematic of Surface Water Handling System at RFP

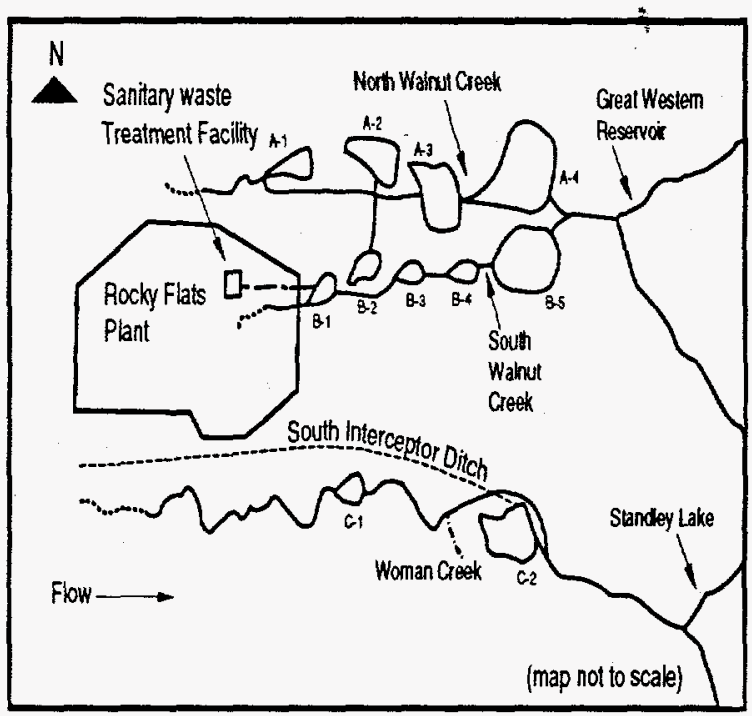

discharge ponds. Pond A-3 collects surface-water diverted around Ponds A-1 and A-2 and a substantial portion 
of the North Walnut Creek and northern plant site runoff. Pond A-3 is operated in a detain, sample, analyze and release mode. Water released from Pond A-3 is transported to Pond $A-4$. Pond $A-4$ was constructed in the 1980s. Ponds B-1 and B-2 were constructed during the early days of plant operation. Ponds B-1 and B-2 are currently used to collect suspect flows or upsets from the sewage treatment plant (STP) operated at RFP. These ponds are currently operated as nondischarge retention ponds. Water from Ponds $\mathrm{B}-1$ and $\mathrm{B}-2$ is transferred to A-2 after characterization. Pond B3 receives treated effluent from the STP. Approximately $10-15 \%$ of the water treated by STP originates from miscellaneous industrial sources. Water from Pond $\mathrm{B}-3$ is released into Ponds B-4 and B-5. Pond B-4 is operated as a flow-through pond. Pond $\mathrm{B}-5$, constructed in the $1980 \mathrm{~s}$, is a terminal pond. Pond $\mathrm{C}-1$ is located on Woman Creek and receives natural flows. An interceptor ditch (South Interceptor Ditch) is located between and parallel to Woman Creek and the southern boundary of the plant complex. The South Interceptor Ditch drains into Pond C-2 which was constructed in the 1980s. Any offsite discharge from RFP is from the terminal ponds (Ponds A-4, B-5 or C-2). One retention pond (the Landfill Pond) is located in an unnamed basin immediately down gradient of the present Landfill. The Landfill Pond was constructed in 1974. It is operated in a zero discharge mode. In addition to natural flows and the South Interceptor Ditch, there are seven ditches or diversion canals in the general vicinity of RFP. The Upper Church, McKay, Kinner, and Reservoir County Ditches cross the site. The Upper
Church Ditch delivers water to Upper Church Lake and Great Western Reservoir. McKay Ditch supplies water to Great Western Reservoir. The Great Western Reservoir is a water supply for the City of Broomfield. Until recently water from Walnut Creek also drained into Great Western Reservoir. The city of Broomfield built the Broomfield Diversion Ditch to divert Walnut Creek around the reservoir. Kinner Ditch and Reservoir County Ditch divert water from Coal Creek and deliver it to Woman Creek and eventually to Standley Lake. Last Chance Ditch flows south of RFP and supplies water to Rocky Flats Lake and Twin Lakes. Smart Ditch diverts water from Rocky Flats Lake and transports it offsite to the east. The South Boulder Diversion Canal, 10cated immediately west of the western RFP boundary, diverts water from South Boulder Creek and delivers it to Ralston Reservoir which is a water supply for the city of Denver.

Eighty-three water samples and 24 sediment samples were collected in support of this project. Over 800 separate chemical analyses were performed on these samples. Water samples were stabilized in the field with nitric acid using established protocols. Water samples were collected monthly from Ponds A-4, B-5 and $\mathrm{C}-2$ as well as the effluent from STP. Ponds A-1, A-2, A-3, B-1, B-2, $B-3, B-4$ and $C-1$ were sampled quarterly. Other locations were sampled a single time. Sediment samples were collected from each of the ponds. A series of sediment samples was collected from the South Interceptor Ditch. Additional samples were collected at locations that may 
be useful for determining movement of radioactivity at RFP.

This project required the analytical measurement of the total alphä activity (gross alpha activity) in the samples, the determination of the amounts of radium, thorium, uranium, plutonium, and americium. These elements represent the major alpha emitting nuclides suspected in the water samples. Below is a brief description of the analytical methods used to make the measurements for this study. They are not given in great detail since they have been used in our previous study or they are standard methods of analysis./24/

The total alpha activity was measured according to procedures developed by the Environmental Protection Agency./25,26/ A precisely measured amount of water was evaporated onto a planchet, flamed and counted for gross alpha activity. The count rates were converted to picocuries per liter (pCi/L).

The gross beta activity was measured according to procedures developed by the Environmental Protection Agency./25,26/ A precisely measured amount of water was evaporated onto a planchet, flamed and counted for gross beta activity. The count rates were converted to picocuries per liter (pCi/L).

The determination of radium in water samples included the following steps. Radium was co-precipitated onto barium sulfate from a given quantity of water. The barium (radium) sulfate was mounted and counted for alpha particles. The procedure used in this study was developed by the Environmental Protection Agency./25/

Thorium concentrations were determined by inductively coupled plasma mass spectrometry (ICP-MS). The usual protocols established for elemental analysis were followed for the determination of this element. The isotope determined for this analysis is 232Th that is naturally occurring. A de-ionized water sample was run in replicate and produced a thorium signal equivalent to $\sim 0.003 \mathrm{pCi} / \mathrm{L}$. This value was subtracted from each sample.

Uranium was determined by thermal ionization mass spectrometry (TIMS). This procedure has been developed in our laboratory and is described in detail in our previous report./24/ The procedure allows the elucidation of the isotopic composition of the uranium in the sample. The following uranium isotopes are determined: $234 \mathrm{U}, 235 \mathrm{U}, 236 \mathrm{U}$, and $238 \mathrm{U}$. 8 The uranium isotope ratios can be used to separate the uranium into its naturally occurring and its anthropogenically produced components.

Plutonium was determined by TIMS. This procedure has been developed in our laboratory and is described in detail in our previous report./24/ The procedure allows for the quantification of the isotopic composition of the plutonium isotopes in the water sample, i.e., ${ }^{239} \mathrm{Pu}$ and $240 \mathrm{Pu}$. Measurement of the $240 \mathrm{Pu} / 239 \mathrm{Pu}$ atom ratio in samples can be used to separate the global fallout component from the RFP component. 
Americium-241 was analyzed by alpha pulse height analysis. The procedure is a standard procedure used in our laboratory. It has been described in detail in our previous report./24/ The 241Am results are reported in Table 6. Two liter water samples were traced with $243 \mathrm{Am}$. Samples were quantified by alpha pulse height analyses techniques.
Count lengths were varied according to the activity of $241 \mathrm{Am}$ present in the sample. A 10,000 minute count length achieves the $0.003 \mathrm{pCi} / \mathrm{L}$ limit of detection required by this study. Values reported in Table 6 that are below $0.003 \mathrm{pCi} / \mathrm{L}$ are indistinguishable from detector background. Table 6 summarizes the alpha activities measured in surface-waters at RFP.

Table 6. Alpha Activities Measured In Surface-Waters at RFP

\begin{tabular}{|c|c|c|c|c|c|c|c|}
\hline $\begin{array}{c}\text { Date } \\
\text { Sampled }\end{array}$ & Pond & $\begin{array}{c}\text { Gross Al- } \\
\text { pha }\end{array}$ & Radium & Thorium & Uranium & Plutonium & Americium \\
\hline & & $\mathrm{pCi} / \mathrm{L}$ & $\mathrm{pCi} / \mathrm{L}$ & $\mathrm{pCi} / \mathrm{L}$ & $\mathrm{pCi} / \mathrm{L}$ & $\mathrm{pCi} / \mathrm{L}$ & $\mathrm{pCi} / \mathrm{L}$ \\
\hline & & & & & & & \\
\hline $05 / 12 / 93$ & $\mathrm{~A} 1$ & 2.6 & 1.0 & 0.000 & 2.15 & 0.0133 & 0.004 \\
\hline $08 / 24 / 93$ & $\mathrm{~A} 1$ & 12.0 & 0.7 & 0.000 & 15.79 & 0.0261 & 0.007 \\
\hline $05 / 12 / 93$ & $\mathrm{~A} 2$ & 9.1 & 3.2 & $-\cdots$ & 5.59 & 0.0032 & -0.002 \\
\hline $08 / 24 / 93$ & $\mathrm{~A} 2$ & 6.1 & 1.5 & 0.000 & 6.41 & 0.0059 & 0.001 \\
\hline $05 / 12 / 93$ & $\mathrm{~A} 3$ & 8.5 & 2.3 & 0.001 & 4.48 & 0.0037 & -0.001 \\
\hline $08 / 24 / 93$ & $\mathrm{~A} 3$ & 4.6 & 1.1 & ---- & 4.54 & 0.0195 & 0.003 \\
\hline $03 / 17 / 93$ & $\mathrm{~A} 4$ & 4.7 & 2.2 & 0.012 & 2.21 & 0.0025 & 0.009 \\
\hline $04 / 21 / 93$ & $\mathrm{~A} 4$ & 6.3 & 3.2 & 0.012 & 2.42 & 0.0036 & -0.002 \\
\hline $05 / 12 / 93$ & $\mathrm{~A} 4$ & 5.5 & 2.7 & 0.002 & 2.53 & 0.0014 & 0.000 \\
\hline $06 / 15 / 93$ & $\mathrm{~A} 4$ & 8.0 & 4.1 & 0.004 & 3.53 & 0.0026 & -0.001 \\
\hline $07 / 15 / 93$ & $\mathrm{~A} 4$ & 1.5 & 1.0 & 0.001 & 1.63 & 0.0014 & 0.000 \\
\hline $08 / 24 / 93$ & $\mathrm{~A} 4$ & 1.1 & 0.7 & $-\cdots$ & 0.90 & 0.0179 & 0.001 \\
\hline $05 / 17 / 93$ & $\mathrm{~B} 1$ & 5.1 & 4.0 & 0.008 & 3.40 & 0.1175 & 0.053 \\
\hline $08 / 24 / 93$ & $\mathrm{~B} 1$ & 7.3 & 2.9 & 0.000 & 3.80 & 0.6855 & 0.017 \\
\hline $05 / 17 / 93$ & $\mathrm{~B} 2$ & 14.1 & 8.8 & $-\cdots$ & 10.97 & 0.2180 & 0.081 \\
\hline $08 / 24 / 93$ & $\mathrm{~B} 2$ & 7.3 & 1.9 & 0.001 & 5.36 & 0.3526 & 0.010 \\
\hline $05 / 13 / 93$ & $\mathrm{~B} 3$ & 0.6 & 1.0 & $-\cdots--$ & 0.32 & 0.0144 & 0.003 \\
\hline $08 / 24 / 93$ & $\mathrm{~B} 3$ & 0.2 & -0.2 & 0.000 & 0.20 & 0.2285 & 0.065 \\
\hline $05 / 13 / 93$ & $\mathrm{~B} 4$ & -1.2 & -0.9 & 0.000 & 1.46 & 0.0352 & 0.015 \\
\hline $08 / 24 / 93$ & $\mathrm{~B} 4$ & 0.1 & 0.0 & $-\cdots$ & 0.20 & 0.0465 & 0.009 \\
\hline $03 / 17 / 93$ & $\mathrm{~B} 5$ & 3.2 & -0.3 & 0.007 & 1.05 & 0.0043 & 0.000 \\
\hline $04 / 21 / 93$ & $\mathrm{~B} 5$ & 5.2 & 3.2 & 0.001 & 1.75 & 0.0101 & 0.002 \\
\hline $05 / 13 / 93$ & $\mathrm{~B} 5$ & -3.0 & 2.4 & $-\cdots$ & 1.08 & 0.0022 & -0.002 \\
\hline $06 / 15 / 93$ & $\mathrm{~B} 5$ & 2.2 & 1.5 & $-\cdots--$ & 0.41 & 0.0018 & 0.000 \\
\hline $07 / 15 / 93$ & $\mathrm{~B} 5$ & 0.4 & 0.3 & 0.000 & 0.65 & 0.0033 & 0.000 \\
\hline & & & & & & & \\
\hline
\end{tabular}


Table 6. (cont) Alpha Activities Measured In Surface-Waters at RFP

\begin{tabular}{|c|c|c|c|c|c|c|c|}
\hline $\begin{array}{c}\text { Date } \\
\text { Sampled }\end{array}$ & Pond & $\begin{array}{c}\text { Gross Al- } \\
\text { pha }\end{array}$ & Radium & Thorium & Uranium & Plutonium & Americium \\
\hline & & pCi/L & pCi/L & pCi/L & pCi/L & pCi/L & pCi/L \\
\hline & & & & & & & \\
\hline $08 / 23 / 93$ & B5 & 1.1 & 0.0 & --- & 0.59 & 0.0057 & -0.001 \\
\hline $05 / 13 / 93$ & C1 & 2.6 & 1.9 & 0.002 & 1.48 & 0.0073 & 0.002 \\
\hline $08 / 23 / 93$ & C1 & 2.5 & 1.0 & 0.000 & 1.96 & 0.0566 & 0.009 \\
\hline $10 / 21 / 92$ & C2 & 5.1 & -0.7 & 0.003 & 1.90 & 0.0547 & 0.019 \\
\hline $03 / 17 / 93$ & C2 & 5.1 & 2.3 & 0.004 & 1.23 & 0.0204 & 0.005 \\
\hline $04 / 15 / 93$ & C2 & 4.9 & 2.0 & 0.002 & 2.68 & 0.0181 & 0.004 \\
\hline $05 / 13 / 93$ & C2 & 6.5 & 2.7 & 0.002 & 3.20 & 0.0305 & 0.011 \\
\hline $06 / 15 / 93$ & C2 & 4.9 & 2.2 & 0.002 & 1.96 & 0.0403 & 0.015 \\
\hline $07 / 15 / 93$ & C2 & 5.5 & 3.7 & 0.001 & 2.91 & 0.0289 & 0.007 \\
\hline $08 / 23 / 93$ & C2 & 4.1 & 1.5 & ---- & 2.50 & 0.0968 & 0.035 \\
\hline $03 / 17 / 93$ & STP & 1.3 & 0.3 & 0.001 & 0.74 & 0.0008 & 0.004 \\
\hline $04 / 21 / 93$ & STP & 1.8 & -0.4 & 0.000 & 1.02 & 0.0021 & 0.000 \\
\hline $05 / 13 / 93$ & STP & 1.1 & 1.0 & ---- & 0.50 & 0.0006 & 0.001 \\
\hline $06 / 15 / 93$ & STP & -0.3 & -0.4 & 0.000 & 0.91 & 0.0013 & -0.002 \\
\hline $07 / 15 / 93$ & STP & 1.2 & 0.7 & 0.000 & 0.54 & 0.0011 & 0.000 \\
\hline
\end{tabular}

The gross alpha activity and the radium concentrations were obtained using procedures developed by the Environmental Protection Agency (EPA)./25,26/ Thorium was measured by ICP-MS. Uranium and plutonium were measured by TIMS. Americium was measured by alpha pulse height analyses techniques.

The majority of the gross alpha activity detected in waters collected from Ponds A-1, A-2, A-3, B-1 and B-2 was the result of activities at RFP. The largest contributor to the alpha activity measured in these ponds was depleted uranium and plutonium. As a first estimation, the alpha activity measured in Pond C-1 can be attributed to naturally occurring uranium and its daughters. The other ponds contain mixtures of naturally occurring and anthropogenic alpha activi- ties. The gross alpha activity is a measure of all the alpha particle contributions from all the contributing alpha emitters. These include the naturally occurring $235 U$ series, $238 U$ series and $232 \mathrm{Th}$. If members of the series are in equilibrium with the parent nuclides of the series, i.e., $235 \mathrm{U}$, $238 \mathrm{U}$ and $232 \mathrm{Th}$, then the total alpha activity attributable to naturally occurring uranium and thorium can be estimated by $n$ times the number of alpha emitters for each series. For $235 \mathrm{U} n$ is 7; for $238 \mathrm{U} \mathrm{n}$ is 8 ; and for 232 Th $n$ is 6 . This relationship establishes the upper limit of alpha activity in a sample that can be attributed to naturally occurring radioactivity for samples where secular equilibrium is maintained. Measurement of the gross alpha activity in waters collected at RFP is a crude screening tool. Gross alpha activity measure- 
ments may under estimate or over estimate the alpha activity levels in water samples. The largest sample aliquot that should be counted for gross alpha activity is an aliquot size that gives a solid density thickness of $5 \mathrm{mg} / \mathrm{cm}^{2}$ on the counting planchet. Surface waters collected at RFP contain significant amounts of dissolved salts. In addition, the salts deposited upon evaporation are hydrophilic. These hydrophilic salts must be converted into stable compounds by flaming before alpha counting. Flaming large amounts of residue produces a non-uniform deposit that may attenuate a portion of the alpha activity and cause the activity levels to be under estimated. Anomalously high total alpha activity levels may also be measured. Uranium and radium form water soluble species. Thorium, plutonium, americium and the short-lived naturally occurring uranium and thorium decay products polonium and bismuth are insoluble and tend to concentrate in the sediments. Incorporation of excessive amounts of sediments may lead to over estimates of the alpha activity in the water samples. Therefore, the total alpha activity levels reported must be interpreted in light of the consequence of the built-in problems associated with gross alpha measurements.

The isotope measured here is radium-226, a member of the $238 \mathrm{U}$ decay series. Radium-226 has a half-life approximately 1600 years. It is produced from the decay of 230Th $(t 1 / 2$ $=80,000$ years). It produces $222 \mathrm{Rn}$ as its decay product. Two other radium isotopes may also be present.

These are ${ }^{223} \mathrm{Ra}(\mathrm{t} 1 / 2=11.1$ days $)$ which is in the natural $235 \mathrm{U}$ series and ${ }^{224} \mathrm{Ra}$ ( $t 1 / 2=3.64$ days) from the natural 232Th series. Depending upon the separation time of the radium from the water and the count time, the degree of equilibrium between the radium isotopes and the parents, and the amounts of each of the three natural series, the radium values may be highly variable. We do not anticipate that ${ }^{223} \mathrm{Ra}$ and ${ }^{224} \mathrm{Ra}$ make a significant contribution to the total radium activity. This, however; does not mean that they are not without value in evaluating the system for alpha activity. These numbers provide an excellent opportunity to estimate the amount of natural alpha activity in the system. Radium is soluble in water and should be present in any natural water system that comes in contact with rock or sediment. All rocks and sediments contain small quantities of naturally occurring uranium and thorium. Consequently, this is a good indicator of the natural component of the alpha activity. There is enough naturally occurring uranium in the water to account for the radium observed in these RFP waters. There is $70-450$ times more alpha activity resulting from the decay of naturally occurring radium than alpha activity resulting from the plutonium in the terminal Ponds A-4, B-5 and $\mathrm{C}-2$.

It is apparent from the results in Table 6 that thorium itself does not contribute significantly to the total alpha activity in the RFP waters. This may be explained by the fact that the solubility of thorium in most natural waters is very low. The two most important members of the decay series that may be soluble are radium and ra- 
don. The range of 232Th concentrations is below detection limit of, 0.003 $\mathrm{pCi} / \mathrm{L}$ to $0.679 \mathrm{pCi} / \mathrm{L}$. The water sample containing $0.679 \mathrm{pCi} 232 \mathrm{Th} / \mathrm{L}$ contained gram quantities of sediments. This sample also contained excessive amounts of uranium and plutonium. The thorium, uranium and plutonium in this sample are most probably associated with the sediment material.
Uranium concentrations measured in the waters collected from the holding ponds at RFP ranged from $0.10 \mathrm{pCi} / \mathrm{L}$ to $15.79 \mathrm{pCi} / \mathrm{L}$. Uranium measurements were obtained by the isotope dilution technique using TIMS. The measurement technique quantifies the 234U, 235U, 236U and 238U content of the water samples. These data are summarized in Table 7.

Table 7. Activity of Specific Uranium Isotopes in Waters

\begin{tabular}{|c|c|c|c|c|c|c|}
\hline $\begin{array}{c}\text { Date Sam- } \\
\text { pled }\end{array}$ & Pond & $\begin{array}{c}\text { Total Ura- } \\
\text { nium }\end{array}$ & U-234 & U-235 & U-236 & U-238 \\
\hline & & pCi/L & pCi/L & pCi/L & pCi/L & pCi/L \\
\hline $05 / 12 / 93$ & A1 & 2.1459 & 0.9466 & 0.0409 & 0.0040 & 1.1544 \\
\hline $08 / 24 / 93$ & $\mathrm{~A} 1$ & 15.7994 & 7.5862 & 0.2202 & 0.0309 & 7.9621 \\
\hline $05 / 12 / 93$ & $\mathrm{~A} 2$ & 5.5906 & 2.4778 & 0.1080 & 0.0105 & 2.9943 \\
\hline $08 / 24 / 93$ & $\mathrm{~A} 2$ & 6.4135 & 2.7534 & 0.1163 & 0.0121 & 3.5317 \\
\hline $05 / 12 / 93$ & $\mathrm{~A} 3$ & 4.4820 & 1.8887 & 0.0783 & 0.0080 & 2.5070 \\
\hline $08 / 24 / 93$ & $\mathrm{~A} 3$ & 4.5453 & 1.8590 & 0.0795 & 0.0090 & 2.5978 \\
\hline $03 / 17 / 93$ & $\mathrm{~A} 4$ & 2.2050 & 0.9906 & 0.0405 & 0.0030 & 1.1708 \\
\hline $04 / 21 / 93$ & $\mathrm{~A} 4$ & 2.4169 & 1.1225 & 0.0445 & 0.0029 & 1.2470 \\
\hline $05 / 12 / 93$ & $\mathrm{~A} 4$ & 2.5389 & 1.2139 & 0.0464 & 0.0029 & 1.2757 \\
\hline $06 / 15 / 93$ & $\mathrm{~A} 4$ & 3.5302 & 1.6457 & 0.0631 & 0.0061 & 1.8153 \\
\hline $07 / 15 / 93$ & $\mathrm{~A} 4$ & 1.6257 & 0.7190 & 0.0302 & 0.0018 & 0.8747 \\
\hline $08 / 23 / 93$ & $\mathrm{~A} 4$ & 0.9049 & 0.4353 & 0.0173 & 0.0010 & 0.4513 \\
\hline $05 / 13 / 93$ & $\mathrm{~B} 1$ & 3.4006 & 1.8045 & 0.0633 & 0.0032 & 1.5296 \\
\hline $08 / 24 / 93$ & $\mathrm{~B} 1$ & 3.8021 & 1.9081 & 0.0735 & 0.0049 & 1.81566 \\
\hline $05 / 13 / 93$ & $\mathrm{~B} 2$ & 10.9670 & 5.0422 & 0.1965 & 0.0259 & 5.7024 \\
\hline $08 / 24 / 93$ & $\mathrm{~B} 2$ & 5.3558 & 2.4584 & 0.0963 & 0.0125 & 2.7886 \\
\hline $05 / 13 / 93$ & $\mathrm{~B} 3$ & 0.3157 & 0.1561 & 0.0059 & 0.0003 & 0.1534 \\
\hline $08 / 24 / 93$ & $\mathrm{~B} 3$ & 0.2017 & 0.1242 & 0.0029 & 0.0001 & 0.0745 \\
\hline $05 / 13 / 93$ & $\mathrm{~B} 4$ & 0.6027 & 0.2650 & 0.0129 & 0.0007 & 0.3241 \\
\hline $08 / 24 / 93$ & $\mathrm{~B} 4$ & 0.2037 & 0.0882 & 0.0046 & 0.0004 & 0.1105 \\
\hline $03 / 17 / 93$ & $\mathrm{~B} 5$ & 1.0507 & 0.5335 & 0.0209 & 0.0007 & 0.4956 \\
\hline $04 / 21 / 93$ & $\mathrm{~B} 5$ & 1.7511 & 0.8914 & 0.0346 & 0.0011 & 0.8240 \\
\hline $05 / 13 / 93$ & $\mathrm{~B} 5$ & 1.0824 & 0.5451 & 0.0217 & 0.0007 & 0.5149 \\
\hline $06 / 15 / 93$ & $\mathrm{~B} 5$ & 0.4086 & 0.1729 & 0.0082 & 0.0003 & 0.2272 \\
\hline $07 / 15 / 93$ & $\mathrm{~B} 5$ & 0.6456 & 0.3081 & 0.0136 & 0.0007 & 0.3232 \\
\hline $08 / 23 / 93$ & $\mathrm{~B} 5$ & 0.5923 & 0.2786 & 0.0129 & 0.0003 & 0.3005 \\
\hline & & & & & & \\
\hline
\end{tabular}


Table 7. (cont) Activity of Specific Uranium Isotopes in Waters

\begin{tabular}{|c|c|c|c|c|c|c|}
\hline $\begin{array}{c}\text { Date Sam- } \\
\text { pled }\end{array}$ & Pond & $\begin{array}{c}\text { Total Ura- } \\
\text { nium }\end{array}$ & U-234 & U-235 & U-236 & U-238 \\
\hline & & $\mathrm{pCi} / \mathrm{L}$ & $\mathrm{pCi} / \mathrm{L}$ & $\mathrm{pCi} / \mathrm{L}$ & $\mathrm{pCi} / \mathrm{L}$ & $\mathrm{pCi} / \mathrm{L}$ \\
\hline $05 / 13 / 93$ & $\mathrm{C} 1$ & 1.4816 & 0.8336 & 0.0287 & ---- & 0.6193 \\
\hline $08 / 24 / 93$ & $\mathrm{C} 1$ & 1.9644 & 1.1230 & 0.0369 & 0.0000 & 0.8045 \\
\hline $12 / 14 / 93$ & $\mathrm{C} 2$ & 2.1286 & 0.9366 & 0.0407 & 0.0038 & 1.1475 \\
\hline $03 / 17 / 93$ & $\mathrm{C} 2$ & 1.2336 & ---- & 0.0418 & ---- & 1.1918 \\
\hline $04 / 15 / 93$ & $\mathrm{C} 2$ & 2.6754 & 1.2378 & 0.0484 & 0.0043 & 1.3849 \\
\hline $05 / 13 / 93$ & C2 & 3.2864 & 1.5118 & 0.0596 & 0.0053 & 1.7097 \\
\hline & & & & & & \\
\hline $07 / 15 / 93$ & C2 & 2.9120 & 1.3359 & 0.0530 & 0.0048 & 1.5183 \\
\hline $08 / 24 / 93$ & C2 & 2.4993 & 1.1405 & 0.0456 & 0.0049 & 1.3083 \\
\hline $03 / 17 / 93$ & STP & 0.7361 & 0.3575 & 0.0147 & 0.0007 & 0.3632 \\
\hline $04 / 15 / 93$ & STP & 1.0177 & 0.4757 & 0.0204 & 0.0010 & 0.5206 \\
\hline $05 / 13 / 93$ & STP & 0.5001 & 0.2217 & 0.0102 & 0.0006 & 0.2692 \\
\hline $06 / 15 / 93$ & STP & 0.9107 & 0.4654 & 0.0178 & 0.0006 & 0.4269 \\
\hline $07 / 15 / 93$ & STP & 0.5452 & 0.2548 & 0.0102 & 0.0005 & 0.2797 \\
\hline $08 / 24 / 93$ & STP & 0.4329 & 0.1736 & 0.0066 & 0.0004 & 0.1623 \\
\hline
\end{tabular}

The total uranium concentrations reported in Table 7 is the sum of the $234 \mathrm{U}, 235 \mathrm{U}, 236 \mathrm{U}$ and $238 \mathrm{U}$ activities determined by TIMS. The uranium activities measured in the RFP surface-water samples are higher than the uranium activities measured in some of the reservoirs in the vicinity. The uranium activity levels in the surface-waters collected at RFP are lower than the uranium activities in some wells and springs in the western United States. Table 8 reports the highest uranium concentration measured in the RFP ponds during this study. The uranium concentrations in the local reservoirs are the mean uranium concentrations measured by RFP in 1988./27/ The values reported for the selected wells and springs in the western United States were single measurements./28-33/
The atom ratio of $238 \mathrm{U}$ to $235 \mathrm{U}$ in naturally occurring uranium is constant. The $238 \mathrm{U} / 235 \mathrm{U}$ atom ratio in naturally occurring uranium is $\$ 37.8$ The $234 \mathrm{U}$ content of naturally occurring uranium may vary slightly in nature. Uranium-234 is a decay product of $238 \mathrm{U}$ and in undisturbed samples the $234 \mathrm{U}$ and $238 \mathrm{U}$ are in secular equilibrium. Uranium-238 alpha decays to form 234Th. Thorium-234 beta decays with a 24.1 day half-life to form ${ }^{234} \mathrm{~Pa}$. Protactinium-234 beta decays with a 6.7 hour half-life to form $234 \mathrm{U}$. Uranium, thorium and protactinium are chemically different and may be separated by natural processes. In addition, the alpha decay of $238 \mathrm{U}$ may physically damage the mineral containing the uranium. Physical damage of the mineral's 
Table 8. Uranium Concentrations in Waters

\begin{tabular}{|l|l|l|}
\hline Location & Description & $\begin{array}{l}\text { Uranium } \\
\text { content } \\
\text { pCi/L }\end{array}$ \\
\hline & & \\
\hline Pond A-1 & RFP Holding Pond & 15.79 \\
\hline Pond A-2 & RFP Holding Pond & 7.25 \\
\hline Pond A-3 & RFP Holding Pond & 5.14 \\
\hline Pond A-4 & RFP Holding Pond & 3.53 \\
\hline Pond B-1 & RFP Holding Pond & 3.80 \\
\hline Pond B-2 & RFP Holding Pond & 10.97 \\
\hline Pond B-3 & RFP Holding Pond & 0.47 \\
\hline Pond B-4 & RFP Holding Pond & 1.46 \\
\hline Pond B-5 & RFP Holding Pond & 1.75 \\
\hline Pond C-1 & RFP Holding Pond & 1.96 \\
\hline Pond C-2 & RFP Holding Pond & 3.20 \\
\hline Boulder & Reservoir & 0.4 \\
\hline Dillon & Reservoir & 0.5 \\
\hline Great Western & Reservoir & 2.05 \\
\hline Ralston & Reservoir & 0.9 \\
\hline Standley & Reservoir & 1.8 \\
\hline${ }^{*}$ Gallup & Well & 328 \\
\hline${ }^{*}$ Santa Fe & Well & 107 \\
\hline${ }^{*}$ Casper & Spring & 881 \\
\hline${ }^{*}$ Craig & Well & 176 \\
\hline${ }^{*}$ La Junta & Well & 497 \\
\hline${ }^{*}$ Pueblo & Well & 168 \\
\hline & & \\
\hline
\end{tabular}

"The wells and spring listed in Table IV do not serve as public water supplies for the towns listed in the table.

crystal lattice may allow water and air containing carbon dioxide to more readily attack the mineral and increase the availability of the $234 \mathrm{U}$ for dissolution. Therefore naturally occurring uranium may be slightly depleted or slightly enriched in $234 \mathrm{U}$ relative to $238 \mathrm{U}$. For example, sea water is $15 \%$ enriched in $234 \mathrm{U}$ rela tive to 238 U. Uranium-236 does not exist in nature. Uranium-236 is produced by neutron capture on $235 \mathrm{U}$.

The presence of $236 U$ in the surfacewater samples collected at RFP and the variable $238 \mathrm{U} / 235 \mathrm{U}$ atom ratios detected in water samples collected from the holding ponds prove that anthropogenic uranium is present. Table 9 summarizes the atom percent of $234 \mathrm{U}, 235 \mathrm{U}, 236 \mathrm{U}$ and $238 \mathrm{U}$ present in each surface-water sample collected at RFP.

Table 9. Atom Percent of Uranium Isotopes Present in RFP Surface-Waters

\begin{tabular}{|c|c|c|c|c|c|}
\hline Date Sampled & Pond & $\begin{array}{c}\% \text { U- } \\
234\end{array}$ & $\%$ U-235 & $\%$ U-236 & $\%$ U-238 \\
\hline & & & & & \\
\hline Natural Uranium & & 0.0057 & 0.7204 & 0.0000 & 99.2739 \\
\hline $05 / 12 / 93$ & $\mathrm{~A} 1$ & 0.0045 & 0.5549 & 0.0018 & 99.4388 \\
\hline $08 / 24 / 93$ & $\mathrm{~A} 1$ & 0.0052 & 0.4339 & 0.0020 & 99.2739 \\
\hline $05 / 12 / 93$ & $\mathrm{~A} 2$ & 0.0045 & 0.5652 & 0.0018 & 99.4284 \\
\hline $08 / 24 / 93$ & $\mathrm{~A} 2$ & 0.0043 & 0.4259 & 0.0018 & 99.4777 \\
\hline $05 / 12 / 93$ & $\mathrm{~A} 3$ & 0.0041 & 0.4897 & 0.0017 & 99.5045 \\
\hline $08 / 24 / 93$ & $\mathrm{~A} 3$ & 0.0039 & 0.4801 & 0.0018 & 99.5142 \\
\hline $03 / 17 / 93$ & $\mathrm{~A} 4$ & 0.0046 & 0.5425 & 0.0014 & 99.4516 \\
\hline $04 / 21 / 93$ & $\mathrm{~A} 4$ & 0.0049 & 0.5588 & 0.0012 & 99.4351 \\
\hline
\end{tabular}


Table 9. (cont) Atom Percent of Uranium Isotopes Present in RFP Surface-Waters

\begin{tabular}{|c|c|c|c|c|c|}
\hline Date Sampled & Pond & $\begin{array}{c}\% U- \\
234\end{array}$ & $\%$ U-235 & $\%$ U-236 & $\% \cup-238$ \\
\hline $05 / 12 / 93$ & $\overline{A 4}$ & 0.0052 & 0.5693 & 0.0012 & 99.4243 \\
\hline $06 / 15 / 93$ & A4 & 0.0049 & 0.5445 & 0.0017 & 99.4488 \\
\hline $07 / 15 / 93$ & $\overline{\mathrm{A} 4}$ & 0.0045 & 0.5417 & 0.0011 & 99.4527 \\
\hline $08 / 23 / 93$ & $\overline{A 4}$ & 0.0053 & 0.6001 & 0.0012 & 99.3935 \\
\hline $05 / 13 / 93$ & $\overline{B 1}$ & 0.0064 & 0.6473 & 0.0011 & 99.3451 \\
\hline $08 / 24 / 93$ & $\overline{B 1}$ & 0.0059 & 0.6340 & 0.0014 & 99.3588 \\
\hline $05 / 13 / 93$ & $\overline{B 2}$ & 0.0048 & 0.5400 & 0.0024 & 99.4528 \\
\hline $08 / 24 / 93$ & $\overline{\mathrm{B} 2}$ & 0.0048 & 0.5414 & 0.0023 & 99.4514 \\
\hline $05 / 13 / 93$ & $\overline{B 3}$ & 0.0055 & 0.6018 & 0.0010 & 99.3916 \\
\hline $08 / 24 / 93$ & $\overline{B 3}$ & 0.0091 & 0.6143 & 0.0009 & 99.3757 \\
\hline $05 / 13 / 93$ & B4 & 0.0045 & 0.6229 & 0.0011 & 99.3715 \\
\hline $08 / 24 / 93$ & $\bar{B} 4$ & 0.0043 & 0.6480 & 0.0018 & 99.3458 \\
\hline $03 / 17 / 93$ & B5 & 0.0059 & 0.6615 & 0.0007 & 99.3319 \\
\hline $04 / 21 / 93$ & $\overline{B 5}$ & 0.0059 & 0.6568 & 0.0007 & 99.3366 \\
\hline $05 / 13 / 93$ & $\overline{B 5}$ & 0.0058 & 0.6593 & 0.0007 & 99.3342 \\
\hline $06 / 15 / 93$ & B5 & 0.0042 & 0.5679 & 0.0008 & 99.4272 \\
\hline $07 / 15 / 93$ & B5 & 0.0052 & 0.6569 & 0.0011 & 99.3368 \\
\hline $08 / 23 / 93$ & $\overline{B 5}$ & 0.0050 & 0.6728 & 0.0006 & 99.3216 \\
\hline $05 / 13 / 93$ & C1 & 0.0073 & 0.7242 & ----- & 99.2684 \\
\hline $08 / 23 / 93$ & $\overline{\mathrm{C} 1}$ & 0.0076 & 0.7176 & 0.0000 & 99.2748 \\
\hline $03 / 17 / 93$ & $\mathrm{C} 2$ & $\cdots$ & 0.5502 & $\cdots$ & 99.4498 \\
\hline $04 / 15 / 93$ & $\overline{C 2}$ & 0.0049 & 0.5471 & 0.0016 & 99.4464 \\
\hline $05 / 13 / 93$ & $\overline{\mathrm{C} 2}$ & 0.0048 & 0.5465 & 0.0016 & 99.4471 \\
\hline $06 / 15 / 93$ & $\mathrm{C} 2$ & 0.0045 & 0.5668 & 0.0011 & 99.4276 \\
\hline $07 / 15 / 93$ & $\overline{C 2}$ & 0.0048 & 0.5469 & 0.0016 & 99.4466 \\
\hline $08 / 24 / 93$ & $\mathrm{C} 2$ & 0.0048 & 0.5426 & 0.0020 & 99.4471 \\
\hline $03 / 17 / 93$ & $\overline{\text { STP }}$ & 0.0054 & 0.6344 & 0.0010 & 99.3592 \\
\hline $04 / 15 / 93$ & STP & 0.0050 & 0.6137 & 0.0010 & 99.3803 \\
\hline $05 / 13 / 93$ & STP & 0.0045 & 0.5907 & 0.0012 & 99.4036 \\
\hline $06 / 15 / 93$ & STP & 0.0059 & 0.6542 & 0.0008 & 99.3391 \\
\hline $07 / 15 / 93$ & STP & 0.0050 & 0.5723 & 0.0009 & 99.4218 \\
\hline $08 / 24 / 93$ & STP & 0.0058 & 0.6390 & 0.0012 & 99.3539 \\
\hline
\end{tabular}


For comparison the atom percentages of $234 \mathrm{U}, 235 \mathrm{U}$ and $238 \mathrm{U}$ in naturally occurring uranium having its $234 \mathrm{U}$ and $238 \mathrm{U}$ in secular equilibrium are also reported. A naturally occurring uranium sample measured on the TIMS used in this study had a $238 \mathrm{U} / 235 \mathrm{U}$ atom ratio of $137.80 \pm$ 0.34 . Sample 08/24/93 A1 measured on the same instrument had a $238 \mathrm{U} / 235 \mathrm{U}$ atom ratio of $229.45 \pm$ 2.29. These values expressed in terms of atom percents $235 \mathrm{U}$ are $(0.7204 \pm 0.0018) \% 235 U$ for the naturally occurring uranium and $(0.4339 \pm 0.0043) \% 235 \mathrm{U}$ for sample $08 / 24 / 93$ A1.

Naturally occurring uranium contains 0.7204 atom percent 235U. Most of the surface-water samples measured at RFP were depleted in $235 \mathrm{U}$. The amount of $235 \mathrm{U}$ present in depleted uranium varies. The majority of depleted uranium produced in this country contains $0.2 \% 235$ to $0.5 \%$ 235U./37/ Table 10 illustrates the maximum amount of depleted uranium that is present in each water sample collected at RFP. The values derived assume a simple two component system. The data reported in Table 10 assume that the depleted uranium released by RFP contains $0.5 \% 235 \mathrm{U}$. This conservative estimate determines the maximum amount of depleted uranium present in the surface-waters.
Table 10. Maximum Percentage of Uranium in Water Attributable to Release of Depleted Uranium at RFP

\begin{tabular}{|c|c|c|}
\hline $\begin{array}{l}\text { Date Sam- } \\
\text { pled }\end{array}$ & Pond & $\underset{U}{\text { "Maximum \% }}$ \\
\hline $05 / 12 / 93$ & $\overline{A 1}$ & 50 \\
\hline $08 / 24 / 93$ & $\overline{A 1}$ & 100 \\
\hline $05 / 12 / 93$ & A2 & 46 \\
\hline $08 / 24 / 93$ & $\overline{A 2}$ & 66 \\
\hline $05 / 12 / 93$ & $\overline{A 3}$ & 80 \\
\hline $08 / 24 / 93$ & $\overline{A 3}$ & 100 \\
\hline $03 / 17 / 93$ & $\overline{\mathrm{A} 4}$ & 58 \\
\hline $04 / 21 / 93$ & $\overline{\mathrm{A} 4}$ & 49 \\
\hline $05 / 12 / 93$ & $\overline{\mathrm{A} 4}$ & 45 \\
\hline $06 / 15 / 93$ & $\overline{A 4}$ & 54 \\
\hline $07 / 15 / 93$ & $\overline{\mathrm{A} 4}$ & 56 \\
\hline $08 / 23 / 93$ & $\overline{\mathrm{A} 4}$ & 31 \\
\hline $05 / 13 / 93$ & B1 & 23 \\
\hline $08 / 24 / 93$ & B1 & 23 \\
\hline $05 / 13 / 93$ & $\overline{B 2}$ & 57 \\
\hline $08 / 24 / 93$ & $\overline{B 2}$ & 56 \\
\hline $05 / 13 / 93$ & $\overline{B 3}$ & 35 \\
\hline $08 / 24 / 93$ & $\overline{\mathrm{B} 3}$ & 36 \\
\hline $05 / 13 / 93$ & $\bar{B} 4$ & 26 \\
\hline $08 / 24 / 93$ & $\overline{B 4}$ & 19 \\
\hline $03 / 17 / 93$ & $\overline{B 5}$ & 18 \\
\hline $04 / 21 / 93$ & B5 & 17 \\
\hline $05 / 13 / 93$ & B5 & 16 \\
\hline $06 / 15 / 93$ & $\overline{B 5}$ & 46 \\
\hline $07 / 15 / 93$ & $\overline{B 5}$ & 16 \\
\hline $08 / 23 / 93$ & $\overline{B 5}$ & 12 \\
\hline $05 / 13 / 93$ & $\overline{C 1}$ & 0 \\
\hline $08 / 23 / 93$ & C1 & 0 \\
\hline $03 / 17 / 93$ & $\overline{\mathrm{C} 2}$ & 52 \\
\hline $04 / 15 / 93$ & $\overline{C 2}$ & 53 \\
\hline $05 / 13 / 93$ & C2 & 53 \\
\hline $06 / 15 / 93$ & $\overline{\mathrm{C} 2}$ & 46 \\
\hline $07 / 15 / 93$ & $\mathrm{C} 2$ & 51 \\
\hline $08 / 24 / 93$ & $\mathrm{C} 2$ & 54 \\
\hline $04 / 15 / 93$ & STP & 29 \\
\hline $05 / 13 / 93$ & STP & 37 \\
\hline
\end{tabular}


* Maximum Percentage of Uranium in Water Attributable to Release of Depleted Uranium at RFP

Estimates are made using the following relationship:

(N238/N235)obs $=\{(\mathrm{N} 238 / \mathrm{N} 235) \mathrm{dep}\}$

$\{\mathrm{F}\}+\{(\mathrm{N} 238 / \mathrm{N} 235)$ nat $\}\{1-\mathrm{F}\}$

(N238/N235)obs is the 238U/235U atom ratio measured in the sample, (N238/N235)dep is the 238U/235U atom ratio in the depleted uranium and (N238/N235)nat is the $238 \mathrm{U} / 235 \mathrm{U}$ atom ratio in naturally occurring uranium. $F$ is the fraction of ${ }^{235} \mathrm{U}$ in the sample that comes from depleted uranium. This equation can be solved to provide an estimate of amount of depleted uranium present in the samples.

The plutonium content of Ponds $A-1$, A-2, A-3, B-1, B-2, B-3, B-4 and C-1 was measured quarterly. The results are presented in Figure 4. The data obtained before October 1, 1992 have been previously reported./24/ The plutonium concentrations observed in Ponds A-2, B-1 and B-2 during November, 1992 are significantly higher than any other measurements of RFP pond waters. These samples contained significant (multiple grams) quantities of sediments. The sediments in the ponds contain more plutonium on a per gram basis than the waters. Sediments may be re-suspended by wind or they may be incorporated during sampling. Inclusion of sediments in water samples can bias analytical results.

Ponds A-4, B-5, C-2 and the effluent from STP were sampled monthly. The plutonium concentrations in these ponds are presented in Figure 5. There appears to be a seasonal variation in the plutonium concentrations in Pond C-2. Plutonium concentrations are higher in the spring and summer than winter.

TIMS measures $239 \mathrm{Pu}$ and $240 \mathrm{Pu}$ separately. The $240 \mathrm{Pu} / 239 \mathrm{Pu}$ atom ratio can be used to distinguish plutonium originating at RFP from Global Fallout. The Global Fallout deposited in the vicinity of RFP has a $240 \mathrm{Pu} / 239 \mathrm{Pu}$ atom ratio of $0.169 \pm$ $0.004 . / 38 /$ The plutonium released by RFP has a $240 \mathrm{Pu} / 239 \mathrm{Pu}$ atom ratio of $0.06 \pm 0.01 . / 39 /$ Table 11 lists the $240 \mathrm{Pu} / 239 \mathrm{pu}$ atom ratios measured in surface-waters collected at RFP. All of the $240 \mathrm{Pu} / 239 \mathrm{Pu}$ atom ratios reported in Table 11 are consistent with the atom ratios of the plutonium released by RFP. 
- Figure 3.

Plutonlum Concentrations In Holding Ponds at RFP that are - Analyzed Quarterly

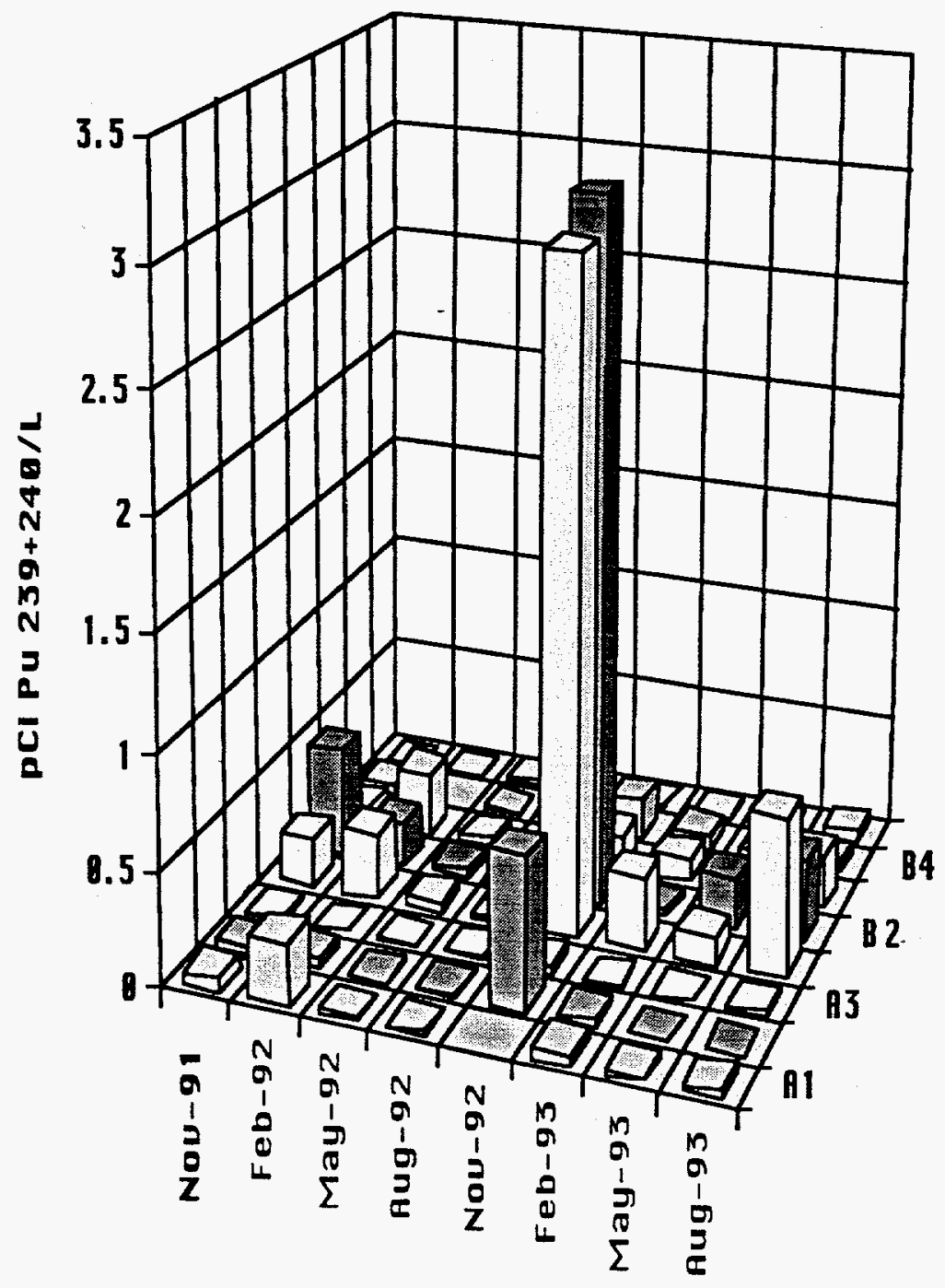




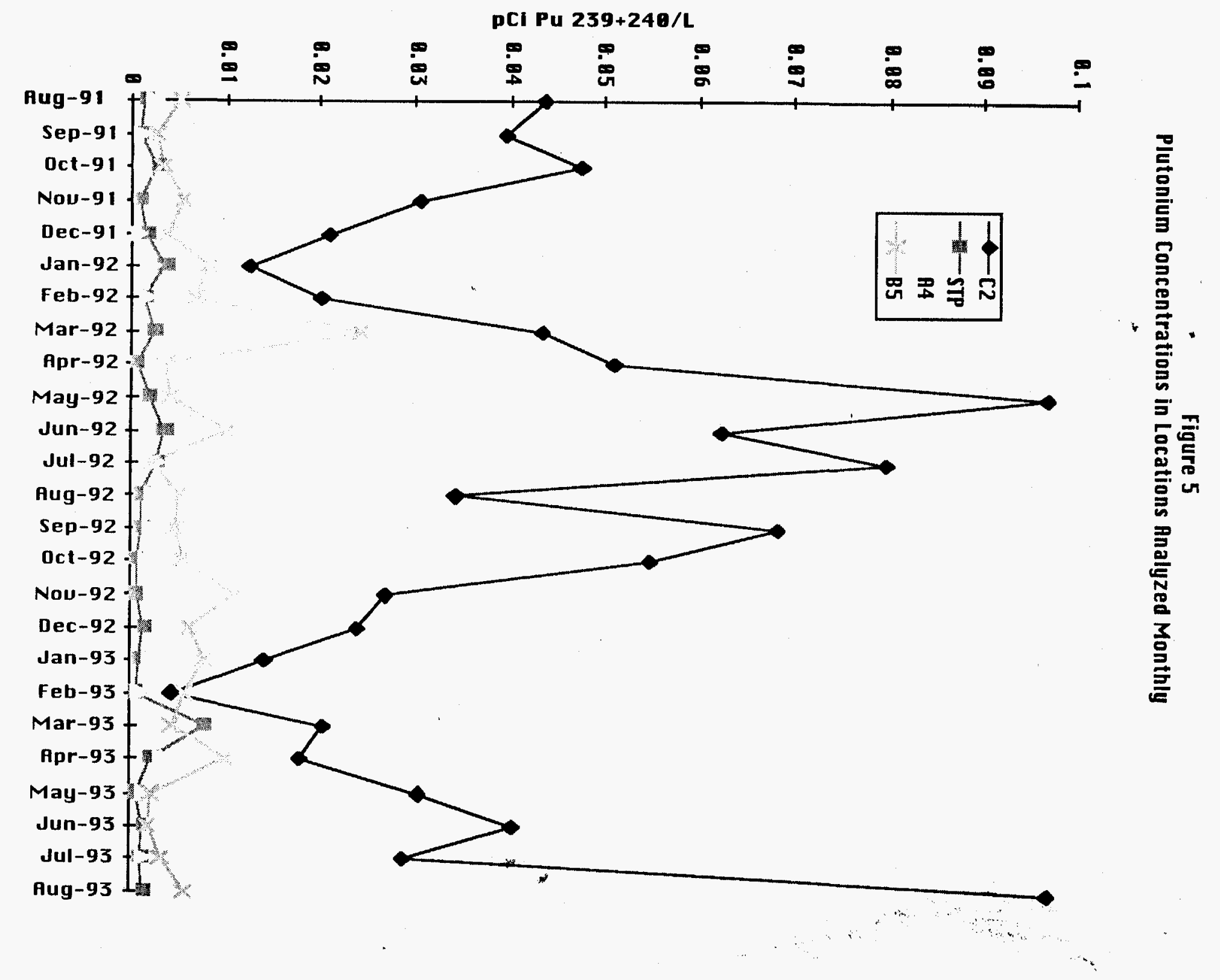


Table 11. 240pu/239pu Atom Ratios Measured in RFP Pond Waters.

\begin{tabular}{|l|l|l|}
\hline Date & Pond & $240 \mathrm{Pu} / 239 \mathrm{Pu}$ \\
\hline & & \\
\hline $05-12-93$ & $\mathrm{~A} 1$ & $0.063+0.009$ \\
\hline $08-24-93$ & $\mathrm{~A} 1$ & $0.055+0.005$ \\
\hline $05-12-93$ & $\mathrm{~A} 2$ & $0.055+0.008$ \\
\hline $05-12-93$ & $\mathrm{~A} 3$ & $0.059+0.005$ \\
\hline $05-17-93$ & $\mathrm{~B} 1$ & $0.061+0.002$ \\
\hline $08-24-93$ & $\mathrm{~B} 1$ & $0.062+0.005$ \\
\hline $05-17-93$ & $\mathrm{~B} 2$ & $0.071+0.006$ \\
\hline $08-24-93$ & $\mathrm{~B} 2$ & $0.061+0.005$ \\
\hline $08-24-93$ & $\mathrm{~B} 3$ & $0.064+0.005$ \\
\hline $11-25-93$ & $\mathrm{~B} 4$ & $0.060+0.003$ \\
\hline $02-24-93$ & $\mathrm{~B} 4$ & $0.066+0.008$ \\
\hline $05-13-93$ & $\mathrm{~B} 4$ & $0.059+0.007$ \\
\hline $08-24-93$ & $\mathrm{~B} 4$ & $0.060+0.005$ \\
\hline $05 / 13 / 93$ & $\mathrm{C} 1$ & $0.069+0.006$ \\
\hline $08-23-93$ & $\mathrm{C} 1$ & $0.057+0.005$ \\
\hline $03-17-93$ & $\mathrm{C} 2$ & $0.056+0.009$ \\
\hline $04-21-93$ & $\mathrm{C} 2$ & $0.056+0.001$ \\
\hline $05-13-93$ & $\mathrm{C} 2$ & $0.062+0.002$ \\
\hline $06-15-93$ & $\mathrm{C} 2$ & $0.055+0.007$ \\
\hline
\end{tabular}

The americium to plutonium alpha activity ratio in materials processed at RFP is not constant. The alpha activity ratio ranges from $0.2-0.4$. This variation is explained by the facts that different batches of plutonium contain different amounts of $241 \mathrm{Pu}$ and the geochemical behavior of plutonium and americium are different. The plutonium content of the water samples was always higher than the americium content. All samples that contained measurable amounts of americium also contained measurable amounts of plutonium.

Table 12 reports the gross beta activity measured in the surface-water samples. The gross alpha activity, uranium alpha activity and radium alpha activity are also included in Table 12.

Table 12. Gross Beta Activity Detected in Surface-Waters at RFP

\begin{tabular}{|c|c|c|c|c|c|}
\hline $\begin{array}{c}\text { Date Sam- } \\
\text { pled }\end{array}$ & Pond & Gross Alpha & Radium & Uranium & Gross Beta \\
\hline & & $\mathrm{pCi} / \mathrm{L}$ & $\mathrm{pCi} / \mathrm{L}$ & $\mathrm{pCi} / \mathrm{L}$ & $\mathrm{pCi} / \mathrm{L}$ \\
\hline & & & & & \\
\hline $02 / 29 / 93$ & $\mathrm{~A} 1$ & 1.5 & -0.3 & 0.73 & -0.9 \\
\hline $05 / 12 / 93$ & $\mathrm{~A} 1$ & 1.5 & 1.0 & 2.15 & 6.3 \\
\hline $08 / 24 / 93$ & $\mathrm{~A} 1$ & 12 & 0.7 & 15.79 & 5.1 \\
\hline $05 / 12 / 93$ & $\mathrm{~A} 2$ & 9.1 & 3.2 & 5.59 & 3.2 \\
\hline $08 / 24 / 93$ & $\mathrm{~A} 2$ & 6.1 & 1.5 & 6.41 & 13.5 \\
\hline $05 / 12 / 93$ & $\mathrm{~A} 3$ & 8.5 & 2.3 & 4.48 & 12.7 \\
\hline $08 / 24 / 93$ & $\mathrm{~A} 3$ & 4.6 & 1.1 & 4.54 & 10.2 \\
\hline $03 / 17 / 93$ & $\mathrm{~A} 4$ & 4.7 & 2.2 & 2.25 & 5.0 \\
\hline $04 / 21 / 93$ & $\mathrm{~A} 4$ & 6.3 & 3.2 & 2.45 & 6.2 \\
\hline $05 / 12 / 93$ & $\mathrm{~A} 4$ & 5.5 & 2.7 & 2.53 & 7.2 \\
\hline $06 / 15 / 93$ & $\mathrm{~A} 4$ & 8.0 & 4.1 & 3.53 & 5.0 \\
\hline $07 / 15 / 93$ & $\mathrm{~A} 4$ & 1.5 & 1.0 & 1.63 & 3.2 \\
\hline $08 / 23 / 93$ & $\mathrm{~A} 4$ & 1.1 & 0.7 & 0.90 & 4.9 \\
\hline $05 / 13 / 93$ & $\mathrm{~B} 1$ & 5.1 & 4.0 & 3.40 & 8.7 \\
\hline
\end{tabular}


Table 12. (cont) Gross Beta Activity Detected in Surface-Waters at RFP

\begin{tabular}{|c|c|c|c|c|c|}
\hline $\begin{array}{c}\text { Date Sam- } \\
\text { pled }\end{array}$ & Pond & Gross Alpha & Radium & Uranium & Gross Beta \\
\hline & & pCi/L & pCi/L & pCi/L & pCi/L \\
\hline & & & & & \\
\hline $08 / 24 / 93$ & B1 & 7.3 & 2.9 & 3.80 & 9.5 \\
\hline $11 / 25 / 92$ & B2 & 12.9 & 2.4 & 6.95 & 18.5 \\
\hline $02 / 23 / 92$ & B2 & 7.0 & 3.1 & 4.79 & 12.9 \\
\hline $05 / 13 / 93$ & B2 & 14.1 & 8.8 & 10.97 & 20.1 \\
\hline $08 / 24 / 93$ & B2 & 7.3 & 1.9 & 5.36 & 10.3 \\
\hline $05 / 13 / 93$ & B3 & 0.6 & 1.0 & 0.32 & 5.9 \\
\hline $08 / 24 / 93$ & B3 & 0.2 & -0.2 & 0.20 & 4.1 \\
\hline $05 / 13 / 93$ & B4 & -1.2 & -0.9 & 0.60 & -0.1 \\
\hline $08 / 24 / 94$ & B4 & 0.1 & 0.0 & 0.20 & 4.1 \\
\hline $03 / 17 / 93$ & B5 & 3.2 & -0.3 & 1.09 & 5.3 \\
\hline $04 / 21 / 93$ & B5 & 5.2 & 3.2 & 1.79 & 3.7 \\
\hline $05 / 13 / 93$ & B5 & -3.0 & 2.4 & 1.08 & 4.2 \\
\hline $07 / 15 / 93$ & B5 & 0.4 & 0.3 & 0.65 & 1.5 \\
\hline $08 / 23 / 93$ & B5 & 1.1 & 0.0 & 0.59 & 3.0 \\
\hline $05 / 13 / 93$ & C1 & 2.6 & 1.9 & 1.48 & 4.3 \\
\hline $08 / 23 / 93$ & C1 & 2.5 & 1.0 & 1.96 & 4.9 \\
\hline $03 / 17 / 93$ & C2 & 5.1 & 2.3 & 2.27 & 4.2 \\
\hline $04 / 15 / 93$ & C2 & 4.9 & 2.0 & 2.65 & 5.5 \\
\hline $05 / 13 / 93$ & C2 & 6.5 & 2.7 & 3.20 & 6.8 \\
\hline $06 / 15 / 93$ & C2 & 4.9 & 2.2 & 1.96 & 6.0 \\
\hline $07 / 15 / 93$ & C2 & 5.5 & 3.7 & 2.91 & 4.9 \\
\hline $08 / 24 / 93$ & C2 & 4.1 & 1.5 & 2.50 & 6.5 \\
\hline $03 / 17 / 93$ & STP & 1.3 & 0.3 & 0.74 & 0.0 \\
\hline $04 / 15 / 93$ & STP & 1.8 & -0.4 & 1.02 & -1.3 \\
\hline $05 / 13 / 93$ & STP & 1.1 & 1.0 & 0.50 & 2.7 \\
\hline $05 / 15 / 93$ & STP & -0.3 & -0.4 & 0.91 & 1.5 \\
\hline $07 / 15 / 93$ & STP & 1.2 & 0.7 & 0.54 & -0.9 \\
\hline $08 / 24 / 93$ & STP & 0.0 & 0.0 & 0.34 & -2.1 \\
\hline & & & & & \\
\hline
\end{tabular}

The gross beta activity is a measure of all the beta particle contributions from all the beta emitters. These include the naturally occurring $235 \mathrm{U}$ series, $238 \mathrm{U}$ series, $232 \mathrm{Th}$ series and $40 \mathrm{~K}$. If members of these series are in radioactive equilibrium with the parent nuclides of the series, i.e., $235 \mathrm{U}, 238 \mathrm{U}$ and $232 \mathrm{Th}$, then the total beta activity attributable to naturally occurring uranium and thorium can be estimated by $n$ times the number of beta emitters for each series. For $235 \mathrm{U} n$ is 4 ; for $238 \mathrm{U} n$ is 6 ; and for ${ }^{232} \mathrm{Th} n$ is 4 . The beta activities resulting from the decay of the uranium and thorium series summed with the beta activity associated with the de- 
cay of $40 \mathrm{~K}$ establish the upper limit of beta activity in a sample that can be attributed to naturally occurring radioactivity.

Measurement of the gross beta activity in waters collected at RFP is a crude screening tool. There is enough naturally occurring uranium and potassium present in the surfacewaters at RFP so that the calculated amount of natural beta emitting radionuclides more than account for the gross beta activity measured in the water samples. The ponds may also contain varying amounts of anthropogenic beta activity. This anthropogenic beta activity is indistinguishable from the naturally occurring beta activity and apparently does not seem to have contributed significantly to the total beta activity levels detected in the water samples.

Plutonium-241 is a beta emitter present in plutonium. The beta decay of the 241 Pu in RFP plutonium does not contribute significantly to the beta activity in the surface-waters at RFP. For example, the highest plutonium concentration measured in this study was detected in the B-1 Pond sediment sample. The sample contained 4.34 $\mathrm{pCi} \quad 238 \mathrm{Pu} / \mathrm{g}, \quad 152.26 \quad \mathrm{pCi}$ $239+240 \mathrm{Pu} / \mathrm{g}$ and $10.8 \mathrm{pCi} 241 \mathrm{Pu} / \mathrm{g}$. These data imply that the $241 \mathrm{Pu} / 239+240 \mathrm{Pu}$ activity ratio in RFP plutonium is approximately 0.07 . Therefore, for every $1 \mathrm{pCi}$ of alpha activity resulting from the decay of $239+240 \mathrm{pu}$ there should be $0.07 \mathrm{pCi}$ of beta activity resulting from the decay of the $241 \mathrm{Pu}$. No significant beta activity can be attributed to the decay products of $241 \mathrm{Am}$.
A $90 \mathrm{~L}$ aliquot of water collected from Pond $\mathrm{C}-2$ was evaporated to dryness. The resulting salts were pressed into a standard counting geometry and analyzed by gamma ray spectrometric measurement techniques. Most radionuclides that decay by beta emission also produce gamma rays during the decay process. $(3 \mathrm{H}, 90 \mathrm{Sr}$, ${ }^{99} \mathrm{Tc},{ }^{147} \mathrm{Pm}$ and 129 are notable exceptions.) Cesium-137, 40 K and the daughters of $238 \mathrm{U}$ were detected in the $90 \mathrm{~L}$ water sample. Cesium-137 is a beta emitting radionuclide that was deposited as global fallout. Potassium-40 is a naturally occurring beta emitting radionuclide. The $137 \mathrm{Cs}$ concentration was measured to be $0.04 \mathrm{pCi} / \mathrm{L}$ and the $40 \mathrm{~K}$ concentration was measured to be 4.5 $\mathrm{pCi} / \mathrm{L}$. The ${ }^{137} \mathrm{Cs}$ activity level is consistent with that expected from global fallout and the $40 \mathrm{~K}$ level, is consistent with levels measured in other waters in Colorado and New Mexico./40,41/ No extraneous radioisotopes were observed.

Sediment samples were collected from each of the ponds at RFP. Soil samples were also collected in the South Interceptor Ditch and at other strategic locations believed to affect surface-waters at RFP. Resuspension of sediments can significantly increase the actinide concentrations in waters. Transport of sediments can relocate the actinides. Percolation of water through the sediments can affect ground waters. The sediment samples collected for this study were analyzed for radioactive content. Sampling locations are summarized in Table 13. Actinides concentrations 
in the sediments are reported in Table 14. Comparison of the plutonium activities reported in Table 6 for water samples to the plutonium activities reported in Table 14 for sediment samples indicates that one gram of sediment from a holding pond contains approximately 50 times more plutonium than 1 liter of water from the pond. The highest plutonium concentrations were detected in sediments collected from Ponds B-1, B-2 and B-3. More plutonium was detected in the sediment collected from the A-1 Bypass than the sediments collected in the $A$ series ponds. The sediment collected from Pond $\mathrm{C}-2$ contained $2.73 \mathrm{pCi} 239+240 \mathrm{Pu} / \mathrm{g}$. No plutonium was detected in the sediment collected at the Coal CreekWoman Creek Headgate. The sediment collected at the Walnut and Indian Sample Pond contained RFP plutonium and anthropogenic uranium. The plutonium content of the sediment sample collected from the Landfill Pond was typical of surface soil samples at RFP./27/ There does not appear to be any evidence that plutonium is accumulating in the Landfill Pond sediments. Figure 6 is a schematic showing the sampling locations in the South Interceptor Ditch.

Table 13. Sediment and Soil Sample Collection Sites

\begin{tabular}{|l|l|}
\hline Location & Description \\
\hline SW092 & A-1 Bypass Sediment \\
\hline SED60392 & A-1Pond Sediment \\
\hline SED60892 & A-2Pond Sediment \\
\hline SED62892 & A-2Pond Sediment \\
\hline SED1392 & A-3Pond Sediment \\
\hline$-\cdot--$ & A-4Pond Sediment \\
\hline SED62392 & B-1Pond Sediment \\
\hline SED63392 & B-3Pond Sediment \\
\hline SED3897 & B-4Pond Sediment \\
\hline SED64392 & B-5 Pond Sediment \\
\hline SED51493 & C-1Pond Sediment \\
\hline C-1P0nd & C-1Pond Sediment \\
\hline SED913 & C-2Pond Sediment \\
\hline SW01593 & Coal Creek Headgate \\
\hline SW097 & LandfillPond Sediments \\
\hline SW054 & South Interceptor Ditch \\
\hline SW070 & South Interceptor Ditch \\
\hline SW044 & South Interceptor Ditch \\
\hline SW044(N) & South Interceptor Ditch \\
\hline SW036 & South Interceptor Ditch \\
\hline SW038 & South Interceptor Ditch \\
\hline SW038A & South Interceptor Ditch \\
\hline SW035 & South Interceptor Ditch \\
\hline SED64892 & Wainut Sample Pond \\
\hline
\end{tabular}

Table 14. Actinide Elements Detected in Sediments and Soils

\begin{tabular}{|l|c|c|c|c|}
\hline Description & Thorium & Uranium & Plutonium & Americium \\
\hline & $\mathrm{pCi} / \mathrm{g}$ & $\mathrm{pCi} / \mathrm{g}$ & $\mathrm{pCi} / \mathrm{g}$ & $\mathrm{pCi} / \mathrm{g}$ \\
\hline & & & & \\
\hline A-1 Bypass Sediment & ---- & 1.86 & 7.624 & 2.268 \\
\hline A-1 Pond Sediment & 1.18 & 4.37 & 2.375 & 0.831 \\
\hline A-2 Pond Sediment & 1.24 & 6.01 & 2.829 & 0.720 \\
\hline A-3 Pond Sediment & 2.26 & 1.67 & 0.674 & 0.235 \\
\hline A-4 Pond Sediment & 1.60 & 1.17 & 0.105 & 0.004 \\
\hline B-1 Pond Sediment & 2.11 & 8.74 & 152.256 & 30.909 \\
\hline B-2 Pond Sediment & 1.09 & 4.16 & 12.973 & 2.727 \\
\hline
\end{tabular}


Table 14. (cont) Actinide Elements Detected in Sediments and Soils

\begin{tabular}{|c|c|c|c|c|}
\hline Description & Thorium & Uranium & Plutonium & Americium \\
\hline & $\mathrm{pCi} / \mathrm{g}$ & $\mathrm{pCi} / \mathrm{g}$ & $\mathrm{pCi} / \mathrm{g}$ & $\mathrm{pCi} / \mathrm{g}$ \\
\hline & & & & \\
\hline & & 0.50 & & 2.818 \\
\hline B-4 Pond Sediment & 1.67 & 1.26 & 1.062 & 0.250 \\
\hline B-5 Pond Sediment & 1.85 & 0.97 & 0.348 & 0.066 \\
\hline C-1 Pond Sediment & 1.62 & 0.57 & $>0.002$ & -0.002 \\
\hline C-1 Pond Sediment & 1.43 & 1.95 & $\overline{\star \star \star \star L I A ~}$ & -0.001 \\
\hline C-2 Pond Sediment & 2.30 & 2.75 & 2.728 & 0.682 \\
\hline Landfill Pond Sediments & $\ldots$ & 0.85 & 0.016 & 0.002 \\
\hline SW054 South Interceptor Ditch & 2.79 & 1.14 & 0.548 & 0.126 \\
\hline SW070 South Interceptor Ditch & 2.22 & 1.00 & 0.094 & 0.024 \\
\hline SW044 South Interceptor Ditch & 1.52 & 0.73 & $\overline{0.014}$ & 0.003 \\
\hline SW044(N) South Interceptor Ditch & 1.92 & 0.80 & 0.016 & 0.006 \\
\hline SW036 South Interceptor Ditch & 1.32 & 1.60 & 0.384 & 0.100 \\
\hline SW038 South Interceptor Ditch & 0.68 & 0.48 & 0.004 & -0.002 \\
\hline SW038A South Interceptor Ditch & $\cdots$ & 1.67 & 0.007 & $\cdots$ \\
\hline SW035 South Interceptor Ditch & 1.65 & 2.54 & 0.158 & 0.041 \\
\hline${ }^{* \star W}$ Walnut and Indian & $\cdots$ & 1.41 & 0.155 & 0.005 \\
\hline 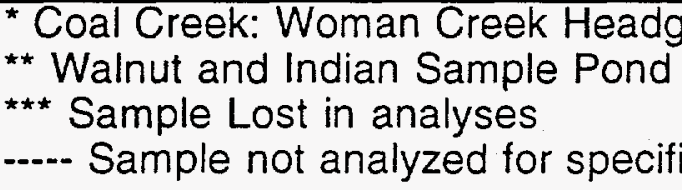 & & & & * \\
\hline
\end{tabular}

Figure 6. Sampling Locations in the South Interceptor Ditch

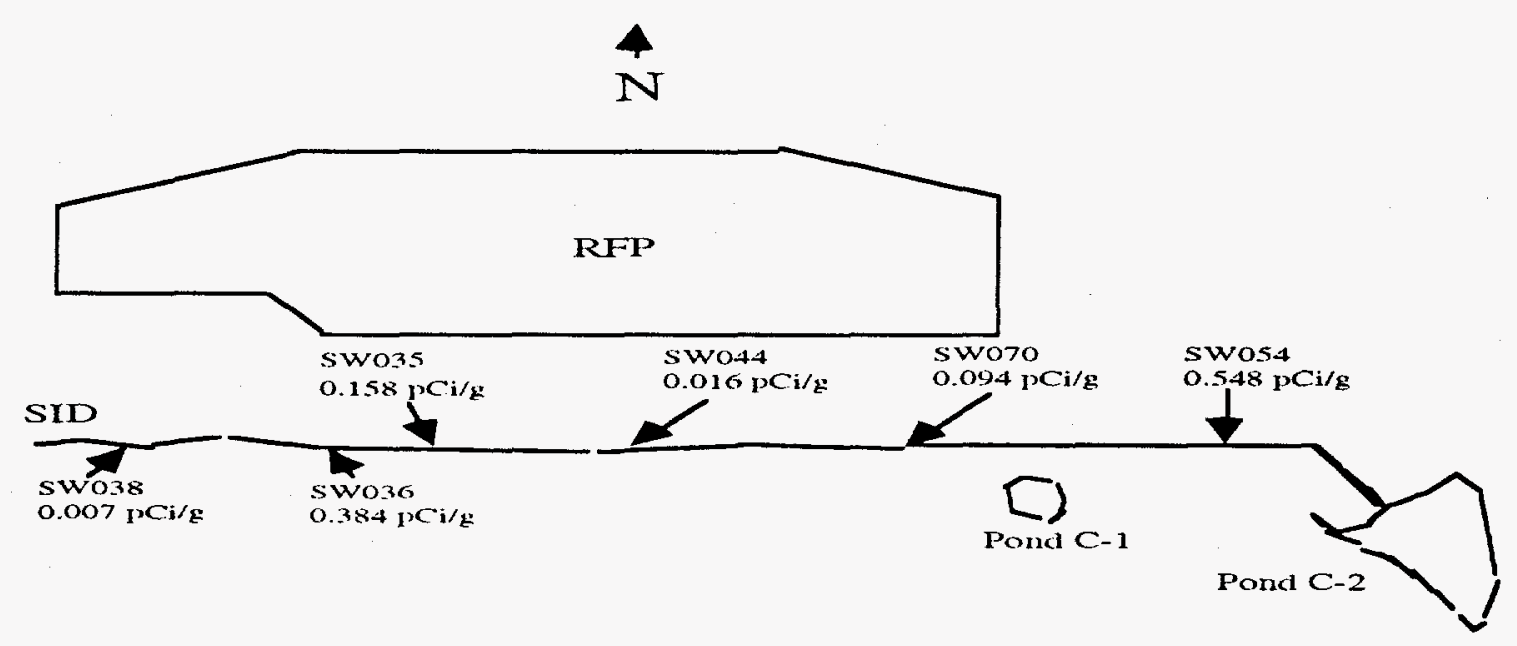


The plutonium appears to be entering the ditch at specific locations below sampling location SW038. The sample collected at sampling location SW038 contained $0.007 \mathrm{pCi} 239+240 \mathrm{Pu} / \mathrm{g}$. The plutonium in this sample had a $240 \mathrm{Pu} / 239 \mathrm{Pu}$ atom ratio of $0.16 \pm 0.03$. The plutonium concentration and isotopic composition of this sample is consistent with global fallout./38,39/ Plutonium seems to be entering the South Interceptor Ditch in the vicinity of sampling locations SW035 and SW036. Sample SW054 contained the highest plutonium concentration measured in the ditch.

The uranium activities at each sampling location are reported in Table 15 and the atom percentages of each uranium isotope are reported in Table 16.

Table 15. Activity of Specific Uranium Isotopes in RFP Sediment and Soil Samples

\begin{tabular}{|l|c|c|c|c|c|}
\hline \multicolumn{1}{|c|}{ Description } & Total Uranium & $\mathrm{U}-234$ & $\mathrm{U}-235$ & $\mathrm{U}-236$ & $\mathrm{U}-238$ \\
\hline & $\mathrm{pCi} / \mathrm{g}$ & $\mathrm{pCi} / \mathrm{g}$ & $\mathrm{pCi} / \mathrm{g}$ & $\mathrm{pCi} / \mathrm{g}$ & $\mathrm{pCi} / \mathrm{g}$ \\
\hline & & & & & \\
\hline A-1 Bypass Sediments & 1.8683 & 0.9314 & 0.0372 & 0.0016 & 0.8981 \\
\hline A-1 Pond Sediment & 4.3673 & 1.3284 & 0.0673 & 0.0138 & 2.9578 \\
\hline A-2 Pond Sediment & 6.0060 & 1.9208 & 0.1015 & 0.0178 & 3.9659 \\
\hline A-3 Pond Sediment & 1.6746 & 0.7660 & 0.0355 & 0.0014 & 0.8717 \\
\hline A-4 Pond Sediment & 1.1691 & 0.5387 & 0.0249 & .0010 & 0.6294 \\
\hline B-1 Pond Sediment & 8.7425 & 3.4191 & 0.1598 & 0.0320 & 5.1316 \\
\hline B-2 Pond Sediment & 4.1631 & 1.9624 & 0.0788 & 0.0080 & 2.1139 \\
\hline B-3 Pond Sediment & 6.5042 & 2.9439 & 0.1136 & 0.0132 & 3.4335 \\
\hline B-4 Pond Sediment & 1.2606 & 0.6038 & 0.0275 & 0.0011 & 0.6282 \\
\hline B-5 Pond Sediment & 0.9693 & 0.4686 & 0.0211 & 0.0004 & 0.4792 \\
\hline C-1 Pond Sediment & 0.5769 & 0.2824 & 0.0129 & 0.0000 & 0.2816 \\
\hline C-1 Pond Sediment & 1.9502 & 1.0181 & 0.0405 & 0.0003 & 0.8913 \\
\hline C-2 Pond Sediment & 2.7589 & 1.1664 & 0.0508 & 0.0057 & 1.5360 \\
\hline Coal Creek & 0.7044 & 0.3626 & 0.0150 & 0.0000 & 0.3268 \\
\hline Landfill Pond Sediments & 0.8500 & 0.4018 & 0.0196 & 0.0000 & 0.4286 \\
\hline South Interceptor Ditch & 1.1429 & 0.5028 & 0.0221 & 0.0019 & 0.6161 \\
\hline South Interceptor Ditch & 1.0044 & 0.4115 & 0.0198 & 0.0017 & 0.5714 \\
\hline South Interceptor Ditch & 0.7308 & 0.3177 & 0.0154 & 0.0007 & 0.3970 \\
\hline South Interceptor Ditch & 0.8002 & 0.4040 & 0.0182 & 0.0002 & 0.3778 \\
\hline South Interceptor Ditch & 1.5972 & 0.5082 & 0.0279 & 0.0044 & 1.0567 \\
\hline South Interceptor Ditch & 0.4754 & 0.2700 & 0.0106 & 0.0006 & 0.2321 \\
\hline South Interceptor Ditch & 2.5442 & 1.0602 & 0.0463 & 0.0053 & 1.4324 \\
\hline South Interceptor Ditch & 1.6658 & 0.8631 & 0.0345 & 0.0002 & 0.7680 \\
\hline
\end{tabular}


Table 16. Atom Percent of Uranium Isotopes Present in RFP Sediments and Soils

\begin{tabular}{|l|l|l|l|l|}
\hline \multicolumn{1}{|c|}{ Description } & U-234 & $U-235$ & $U-236$ & $U-238$ \\
\hline \multicolumn{1}{|c|}{ Natural Uranium } & & & & \\
\hline & 0.0057 & 0.7204 & 0.0000 & 99.2739 \\
\hline A-1 Bypass Sediments & 0.0056 & 0.6483 & 0.0009 & 99.3452 \\
\hline A-1 Pond Sediment & 0.0025 & 0.3571 & 0.0024 & 99.6380 \\
\hline A-2 Pond Sediment & 0.0026 & 0.4017 & 0.0023 & 99.5933 \\
\hline A-3 Pond Sediment & 0.0048 & 0.6383 & 0.0009 & 99.3561 \\
\hline A-4 Pond Sediment & 0.0047 & 0.6183 & 0.0008 & 99.3763 \\
\hline B-1 Pond Sediment & 0.0036 & 0.4884 & 0.0033 & 99.5047 \\
\hline B-2 Pond Sediment & 0.0051 & 0.5842 & 0.0020 & 99.4087 \\
\hline B-3 Pond Sediment & 0.0048 & 0.5186 & 0.0020 & 99.4747 \\
\hline B-4 Pond Sediment & 0.0052 & 0.6861 & 0.0010 & 99.3077 \\
\hline B-5 Pond Sediment & 0.0053 & 0.6888 & 0.0004 & 99.3054 \\
\hline C-1 Pond Sediment & 0.0055 & 0.7166 & 0.0000 & 99.2779 \\
\hline C-1 Pond Sediment & 0.0062 & 0.7107 & 0.0002 & 99.2829 \\
\hline C-2 Pond Sediment & 0.0041 & 0.5185 & 0.0019 & 99.4755 \\
\hline Coal Creek & 0.0060 & 0.7230 & 0.0000 & 99.2709 \\
\hline Landfill Pond Sediments & 0.0051 & 0.7150 & 0.0000 & 99.2799 \\
\hline South Interceptor Ditch & 0.0044 & 0.5614 & 0.0016 & 99.4325 \\
\hline South Interceptor Ditch & 0.0039 & 0.5426 & 0.0016 & 99.4519 \\
\hline South Interceptor Ditch & 0.0044 & 0.6094 & 0.0009 & 99.3853 \\
\hline South Interceptor Ditch & 0.0058 & 0.7520 & 0.0003 & 99.2419 \\
\hline South Interceptor Ditch & 0.0026 & 0.4145 & 0.0022 & 99.5807 \\
\hline South Interceptor Ditch & 0.0063 & 0.7166 & 0.0000 & 99.2771 \\
\hline South Interceptor Ditch & 0.0040 & 0.5067 & 0.0019 & 99.4873 \\
\hline South Interceptor Ditch & 0.0061 & 0.7026 & 0.0001 & 99.2911 \\
\hline
\end{tabular}


Depleted uranium was deteçted in the sediments collects from the $A$ and $B$ series ponds. Depleted uranium was also detected in sediments collected from the South Interceptor Ditch, Pond C-2, Walnut and Indian Sampling Pond and the A-1 Bypass. No anthropogenic uranium was detected in sediments collected at the Coal Creek-Woman Creek Headgate, the Landfill Pond or Pond C-2. Anthropogenic uranium appears to be entering the South Interceptor Ditch at specific locations. Table 17 reports the maximum percentage of uranium present in each sediment sample attributable to depleted uranium. The same algorithm was used for water and sediment samples. Sediment samples from the ponds and the South Interceptor Ditch were analyzed by gamma spectroscopy. The results are summarized in Table 18. The $40 \mathrm{~K}$ concentrations are consistent with previous measurements of naturally occurring radioactive potassium concentrations in surface samples collected in the RFP vicinity and the ${ }^{137} \mathrm{Cs}$ concentrations are consistent with expected radio-cesium concentrations resulting from global fallout./ $40,41 /$ Thallium-208, $214 \mathrm{Bi}$, ${ }^{226} \mathrm{Ra}$ and $228 \mathrm{Ac}$ are naturally occurring radionuclides that are formed by the radioactive decay of $238 \mathrm{U}$ and $232 T$. These radionuclides were detected in the concentrations expected from the decay of naturally occurring uranium and thorium
Table 17. Maximum Percentage of Uranium in Sediments and Soils Attributable to Depleted Uranium

\begin{tabular}{|l|c|}
\hline Description & $\begin{array}{c}\text { Maximum } \\
\%\end{array}$ \\
\hline & \\
\hline & 19 \\
\hline A-1 Bypass Sediments & 100 \\
\hline A-1 Pond Sediment & 100 \\
\hline A-2 Pond Sediment & 21 \\
\hline A-3 Pond Sediment & 28 \\
\hline A-4 Pond Sediment & 80 \\
\hline B-1 Pond Sediment & 40 \\
\hline B-2 Pond Sediment & 65 \\
\hline B-3 Pond Sediment & 8 \\
\hline B-4 Pond Sediment & 8 \\
\hline B-5 Pond Sediment & 0 \\
\hline C-1 Pond Sediment & 2 \\
\hline C-1 Pond Sediment & 91 \\
\hline C-2 Pond Sediment & 0 \\
\hline $\begin{array}{l}\text { Coal Creek:Woman } \\
\text { Creek }\end{array}$ & 0 \\
\hline Landfill Pond Sedi- \\
ments
\end{tabular}

* Maximum Percentage of Uranium Attributable to release of Depleted Uranium from Rocky Flats 
Table 18. Activities Detected in Sediment and Soil Samples by Gamma Spectroscopy

\begin{tabular}{|l|c|c|c|c|c|c|c|}
\hline Location & $\begin{array}{c}40 \mathrm{~K} \\
\mathrm{pCi} / \mathrm{g}\end{array}$ & $\begin{array}{c}137 \mathrm{Cs} \\
\mathrm{pCi} / \mathrm{g}\end{array}$ & $\begin{array}{c}208 \mathrm{TI} \\
\mathrm{pCi} / \mathrm{g}\end{array}$ & $\begin{array}{c}214 \mathrm{Bi} \\
\mathrm{pCi} / \mathrm{g}\end{array}$ & $\begin{array}{c}226 \mathrm{Ra} \\
\mathrm{pCi} / \mathrm{g}\end{array}$ & $\begin{array}{c}228 \mathrm{Ac} \\
\mathrm{pCi} / \mathrm{g}\end{array}$ & $\begin{array}{c}241 \mathrm{Am} \\
\mathrm{pCi} / \mathrm{g}\end{array}$ \\
\hline & & & & & & & \\
\hline $\mathrm{A}-1$ & 19.1 & 0.5 & 1.9 & 2.2 & 2.6 & 2.0 & ${ }^{* *} \mathrm{ND}$ \\
\hline $\mathrm{A}-2$ & 20.0 & 1.1 & 1.9 & 3.4 & 3.1 & 1.7 & $\mathrm{ND}$ \\
\hline $\mathrm{A}-3$ & 18.6 & 0.2 & 3.1 & 1.1 & 1.9 & 2.5 & $\mathrm{ND}$ \\
\hline $\mathrm{A}-4$ & 21.3 & 0.1 & 2.2 & 2.2 & 3.8 & 2.0 & $\mathrm{ND}$ \\
\hline $\mathrm{B}-1$ & 19.9 & 0.8 & 2.5 & 4.0 & 2.6 & 2.1 & 25.1 \\
\hline $\mathrm{B}-2$ & 19.3 & 0.2 & 1.8 & 2.1 & 3.1 & 3.0 & 3.0 \\
\hline $\mathrm{B}-3$ & 21.0 & 0.4 & 4.1 & 1.8 & 2.7 & 1.2 & 2.7 \\
\hline $\mathrm{B}-4$ & 17.4 & 0.4 & 3.7 & 2.6 & 2.3 & 2.2 & $\mathrm{ND}$ \\
\hline $\mathrm{B}-5$ & 26.0 & 0.2 & 2.0 & 2.7 & 1.4 & 1.9 & $\mathrm{ND}$ \\
\hline $\mathrm{C}-1$ & 15.1 & 0.9 & 1.9 & 2.6 & 1.9 & 0.9 & $\mathrm{ND}$ \\
\hline $\mathrm{C}-2$ & 19.6 & 0.4 & 2.7 & 1.9 & 2.7 & 3.1 & $\mathrm{ND}$ \\
\hline${ }^{\star} \mathrm{SID}$ & 22.9 & 0.6 & 3.1 & 0.3 & 2.6 & 2.6 & $\mathrm{ND}$ \\
\hline SID & 22.1 & 0.1 & 3.0 & 2.4 & 2.3 & 2.5 & $\mathrm{ND}$ \\
\hline SID & 17.6 & 0.7 & 2.1 & 1.3 & 2.9 & 1.6 & $\mathrm{ND}$ \\
\hline SID & 18.1 & 1.1 & 2.6 & 3.3 & 2.1 & 1.4 & $\mathrm{ND}$ \\
\hline SID & 19.0 & 0.3 & 2.2 & 3.6 & 1.7 & 2.1 & $\mathrm{ND}$ \\
\hline SID & 24.9 & 0.6 & 3.7 & 2.0 & 2.4 & 3.1 & $\mathrm{ND}$ \\
\hline SID & 22.1 & 0.3 & 3.4 & 1.7 & 2.7 & 1.4 & $\mathrm{ND}$ \\
\hline
\end{tabular}

SID = South Interceptor Ditch

** $\mathrm{ND}=\mathrm{No}{ }^{241} \mathrm{Am}$ detected in the sample by gamma spectroscopy

in the sediment samples. All radionuclides detected in the sediment samples were naturally occurring or the results of global fallout or processes at RFP. A series of special water samples was collected. Samples collected at the Raw Water Pond and the B-124 Treatment Facility were collected as part of an effort to locate the source of the depleted uranium detected in the effluent of the Sewage Treatment Plant. The Coal Creek-Woman Creek Headgate water sample was collected to assess water quality upstream from RFP. This sample provides a base-line for the uranium content of water in the creek prior to entry to RFP. The water sample collected at the Land Fill Pond was collected to assess the quality of the water percolating out of the Land Fill. The Boulder Canal sample assesses the quality of water in the canal. The sample collection dates and sampling locations are summarized in Table 19. 
Table 19. Special Water Sample Collection Sites

\begin{tabular}{|c|l|}
\hline $\begin{array}{c}\text { Date Sam- } \\
\text { pled }\end{array}$ & \multicolumn{1}{|c|}{ Description } \\
\hline & \\
\hline $08 / 12 / 93$ & Raw Water Pond \\
\hline $08 / 19 / 93$ & $\begin{array}{l}\text { OU-4 West Holding } \\
\text { Tank }\end{array}$ \\
\hline $08 / 12 / 93$ & Landfill Pond \\
\hline $08 / 12 / 93$ & Coal Creek Headgate \\
\hline $09 / 08 / 93$ & Boulder Canal \\
\hline $08 / 12 / 93$ & Raw Water Pond \\
\hline $09 / 08 / 93$ & B-124 Treated Water \\
\hline $09 / 08 / 93$ & B-124 Raw Water \\
\hline
\end{tabular}

The uranium and plutonium concentrations measured in the waters are reported in Table 20.

Table 20. Uranium and Plutonium Concentrations in Special Water Samples

\begin{tabular}{|l|c|c|}
\hline Description & Uranium & Plutonium \\
\hline & $\mathrm{pCi} / \mathrm{g}$ & $\mathrm{pCi} / \mathrm{g}$ \\
\hline & & \\
\hline $\begin{array}{l}\text { Raw Water } \\
\text { Pond }\end{array}$ & 0.38 & 0.0002 \\
\hline OU-4 & 78.15 & 0.0030 \\
\hline Landfill Pond & 2.21 & 0.0030 \\
\hline Coal Creek & 0.77 & 0.0001 \\
\hline Boulder Canal & 0.42 & 0.0015 \\
\hline $\begin{array}{l}\text { Raw Water } \\
\text { Pond }\end{array}$ & 0.37 & 0.0002 \\
\hline B-124 Treated & 0.10 & 0.0002 \\
\hline B-124 Raw & 0.37 & 0.0001 \\
\hline
\end{tabular}

No RFP plutonium or anthropogenic uranium was detected in the Raw Water Pond or the influent or effluent waters collected at the potable water treatment facility, B-124. The source of the depleted uranium in the efflu- ent from STP has not been positively identified. No anthropogenic uranium was detected in the water sample collected at the Landfill Pond. The plutonium concentration was at our limit of detection. We found no evidence that the Landfill Pond is affecting the uranium or plutonium contents of surface-waters at RFP. No anthropogenic uranium or RFP plutonium was detected in the water sample collected from the Boulder Canal. We found no evidence that processes at RFP have affected the water in the canal.

The water sample collected from the OU-4 West Holding Tank contained the highest concentration of uranium that we have measured to date. The uranium contained 0.8337 atom percent $235 \mathrm{U}$ and 0.0064 atom percent $236 \mathrm{U}$. This indicates that the sample contains enriched uranium. This is the only sample collected to date that contains any enriched uranium.

$*$

The following conclusions are made concerning radioactivity in the water and sediment samples collected at RFP. The largest source of anthropogenic radioactivity presently affecting surface-waters at RFP is the sediments that are currently residing in the holding ponds. One gram of sediment from a holding pond contains approximately 50 times more plutonium than 1 liter of water from the pond. Two other specific locations have been identified that may affect surface-waters at RFP. Plutonium and depleted uranium appear to be moving down the South Interceptor Ditch and through the $A-1$ Bypass. The upper Ponds A-1, A-2, A-3, B-1, B-2, B3 , and $B-4$ contain measurable quan- 
tities of plutonium, americium, and depleted uranium. The plutonium concentrations in these ponds ranged from 0.004 to $3.09 \mathrm{pCi}$ $239+240 \mathrm{Pu} / \mathrm{L}$. The uranium concentrations ranged from 0.2 to $15.8 \mathrm{pCi} / \mathrm{L}$. Essentially $100 \%$ of the uranium in Pond $\mathrm{A}-1$ and Pond $\mathrm{A}-2$ originated as depleted uranium. All other ponds, except Pond C-1, contain mixtures of naturally occurring and depleted uranium. No depleted uranium was detected in Pond C-1. The largest source of radioactivity in the terminal Ponds A-4, B-5 and C-2 was naturally occurring uranium and its decay product radium. There is $70-450$ times more alpha activity resulting from the decay of naturally occurring radium than alpha activity resulting from the plutonium in the terminal ponds. Plutonium and americium concentrations in the terminal ponds were consistent with the values published in our previous report. The largest source of anthropogenic radioactivity in the terminal ponds was depleted uranium. Approximately half of the uranium present in Ponds A-4 and $\mathrm{C}-2$ originated as depleted uranium. Approximately $20 \%$ of the uranium in the waters collected from Pond B-5 originated as depleted uranium. All of the radioactivity observed in soil, sediment and water samples collected at RFP was naturally occurring, the result of processes at RFP or the result of global fallout. No extraneous anthropogenic alpha, beta or gamma activities were detected. Approximately one-third of the uranium present in the effluent from the Sewage Treatment Plant (STP) originated as depleted uranium. No depleted uranium was detected in the Raw Water Pond that supplies the water processed at STP. No plutonium or anthropogenic uranium was detected in the influent or effluent from the Water Treatment Facility at B-124. The source of depleted uranium in the effluent from STP has not been positively identified. No uranium or plutonium attributable to RFP was detected in sediments collected at the Coal Creek-Woman Creek Headgate. Plutonium and depleted uranium were detected in sediments collected from the Walnut and Indian Street Sampling Pond. This indicates that the depleted uranium and plutonium are entering the surface-waters at the RFP site. Plutonium and depleted uranium were detected in soil samples collected from the South Interceptor Ditch. The plutonium and uranium concentrations varied from location to location within the South Interceptor Ditch. This suggests that these materials are entering the ditch at specific places. The uranium in the sediments collected from Pond C- 1 is naturally occurring uranium. Approximately $50 \%$ of the uranium detected in the waters and $90 \%$ of the uranium detected in the sediment sample collected from Pond C-2 were anthropogenic. This implies that the depleted uranium is being transported down the South Interceptor Ditch by water into Pond C-2. Radium activities in the water samples were consistent with the activities predicted to be present from the naturally occurring uranium. In general the radium activities were lower than the total uranium activities. This is explained by the fact that the water samples contained depleted uranium. The radium is chemically separated during uranium processing. The depleted uranium released into the environment did not contain large amounts of radium. The plutonium 
concentrations in Pond C-2 appear to vary seasonally.

\section{Conclusions}

Identification of nuclear signatures by analyzing bulk samples is a viable technique. The technique can be used to resolve the radioactive constituents of a sample into its anthropogenic and naturally occurring radioactive components. In certain instances, when more than one source of anthropogenic radioactive contamination is suspected, the techniques can be used to identify the sources of the radioactivity. If both sources are present, the fingerprinting may furnish information on the relative contributions of each source. The techniques developed for analyzing bulk samples to isotopically fingerprint the anthropogenic radioactive components have many applications including environmental monitoring, non-proliferation studies at specific locations and wide area monitoring.

\section{References}

/1/ A. Aakrog, "Radioactivity in Polar Regions--Main Sources," in Environmental Radiochemistry in the Arctic and Antarctic, P. Strands and E. Holm eds., pp 15-34 (1993).

12/ P. R. Pryde and D. J. Bradley, "The Geography of Radioactivity Contamination in the Former USSR," PostSoviet Geography, 35, 557-593 (1994).

/3/ U. S. Congress, "Nuclear Waste in the Arctic: An Analysis of Arctic and Other Regional Impacts from Soviet Nuclear Contamination," Office of
Technology Assessment report OTAENV-623 (1995).

14/ B. F. Myasoedov, V. N. Kosyakov, A. P. Novikov and G. N. Romanov, "Actinide Science Relevant to the Environment, Radioactive Waste Management and Remediation," presented at the USAIFSU Workshop on . Actinides in the Environment, Dublin, California, August 15-18, 1995, Sponsored by Institute for Transuranium Science, Lawrence Livermore National Laboratory, Livermore, CA 94551.

/5/ G. E. Bentley, W. R. Daniels, G. W. Knobeloch, F. O. Lawrence and D. C. Hoffman, "Separation and Analysis of Plutonium in Soil," in Proceedings of Environmental Plutonium Symposium held at LASL, August 4-5, 1971, Los Alamos Scientific Laboratory document LA-4756 (1971).

/6/ G. W. Knobeloch, "The Dissolution of Underground Nuclear Debris Samples," in Collected Radiochemical and Geochemical Procedures, J. Kleinberg ed., Los Alamos National Laboratory document LA-1721, 5th Ed. (1990).

/7/ G. W. Knobeloch, V. M. Armijo and D. W. Efurd, "Separation of Uranium and Plutonium from Underground Nuclear Debris for Mass Spectrometric Analyses," in Collected Radiochemical and Geochemical Procedures, J. Kleinberg ed., Los Alamos National Laboratory document LA1721, 5th Ed. (1990).

18/ R. E. Perrin, G. W. Knobeloch, V. M. Armijo and D. W. Efurd, HighPrecision Isotopic Analyses of Nanogram Quantities of Plutonium, 
Los Alamos National Laboratory document LA-10013-MS (1984);

19/ R. E. Perrin, G. W. Knobeloch, V. M. Armijo and D. W. Efurd, "Isotopic Analyses of Nanogram Quantities of Plutonium by using a SID Ionization Source," Int. J. Mass Spectrom. Ion. Processes, 64 (1985).

/10/ T. D. Filer, "Cesium (Radioactive) in Waste Water-Phosphomolybdate Procedure," in Health and Environmental Chemistry: Analytical Techniques, Data Management, and Quality Assurance, M. A. Gautier, ed., Los Alamos National Laboratory document LA-10300-M, Vol. III (1993).

/11/M. A. Wade, and H. J. Seim, "Ion Exchange Separation of Calcium and Strontium," Anal. Chem. 33, 793 (1961).

/12/ D. W. Efurd and F. R. Roensch, "Americium and Curium II," in Collected Radiochemical and Geochemical Procedures, J. Kleinberg ed., Los Alamos National Laboratory document LA-1721, 5th Ed. (1990).

/13/W. R. Shields, ed., NBS Technical Note 426, U. S. Government Printing Office, Washington, D. C. 20402, 53 pp (1967).

/14/ J. C. Banar, R. E. Perrin and R. Ostrenga, U. S. Patent 4745277 (1986).

/15/ M. M. Fowler, M. R. Betts and J. Headstream, CST-11 Counting Room Users Guide, Los Alamos National Laboratory report LA-UR94-3698 (October, 1994).
116/ P. W. Krey, E. P. Hardy, C. Pachucki, F. Rourke, J. Coluzza and W. K. Benson, "Mass Isotopic Composition of Global Fall-Out Plutonium in Soil," in Proceedings of a Symposium on "Transuranium Nuclides in the Environment," San Francisco, 17-21 November 1975, International Atomic Energy Agency report STI/PUB/410 (1976).

/17/ H. G. Hicks and D. W. Barr, "Nevada Test Site Fallout Atom Ratios: 240Pu/239Pu and 241Pu/239Pu," Lawrence Livermore National Laboratory report UCRL53499/1 (1984).

/18/ M. Yamamoto, A. Tsumura, Y. Katayama and T. Tsukatani, "Plutonium Isotopic Composition in Soil from the Former Semipalatinsk $\mathrm{Nu}$ clear Test Site," Radiochemica Acta, 72, 209-215 (1996).

/19/ P. W. Krey and B. T. Krajewski, "Plutonium Isotopic Ratios at Rocky Flats," U. S. A.E.C. Report HASL249, I-67 (1972).

120/ D. W. Efurd, D. J. Rokop and R. E. Perrin, "Characterization of the Radioactivity in Surface-Waters and Sediments Collected at the Rocky Flats Facility," Los Alamos National Laboratory Report LA-UR93-4373 (1994).

121/ T. K. Li, J. L. Parker, H. G. Wagner, J. Goerten, R. Wellum and K. Kammerichs, "Plutonium Analyses of High-Burn-up Spent-Fuel Dissolver Solutions by Low-Energy GammaRay Spectrometry," Los Alamos Na- 
tional Laboratory report LA-UR-931726 (1993).

/22/ "Final Surface-Water Interim Measures/Interim Remedial Action Plan/Environmental Decision Document- South Walnut Creek Basin (OU-2)," U. S. Department of Energy report, March, 1991.

/23/ Seed, J. R., K. W. Calkins, C. T. Illsley, F. J. Miner and J. B. Owne, RFP-INV-10, "Committee Evaluation of Plutonium Levels in Soil Within and Surrounding USAEC Installation at Rocky Flats, Colorado," Prepared under contract AT (29-1)-1106 for the Albuquerque Operations Office U. S. Atomic Energy Commission, report RFP-INV-10, July, 1971.

124/ Efurd, D. W., D. J. Rokop and R. E. Perrin, "Actinide Determination and Analytical Support for Water Characterization and Treatment Studies at Rocky Flats, "Los Alamos National Laboratory report LA-UR-93917, February, 1993.

/25/ Krieger, H. L. and E. L. Whittaker, "Prescribed Procedures for Measurements of Radioactivity in Drinking Water," Environmental Protection Agency report EPA-600/4/80-032, August, 1980.

/26/ Johns, F. B., P. B. Hahn, D. J. Thome and E. W. Bretthauer, "Radiochemical Analytical Procedures for Analyses of Environmental Samples," Environmental Protection Agency report EMSL-LV-0539-127, March, 1979.

/27/ N. M. Daughtry Ed., "Rocky Flats Site Environmental Report For 1988,"
Rocky Flats report RFP-ENV-88, May, 1989.

/28/ Morgan, T.L. and J. D. Purson, "Uranium Hydrogeochemical and Stream Sediment Reconnaissance of the Shiprock NTMS Quadrangle, New Mexico/Arizona, Including Concentrations of Forty-two Additional Elements," Los Alamos National Laboratory report LA-7513-MS, 1980.

/29/ L. W. Maassen, "Uranium Hydrogeochemical and Stream Sediment Reconnaissance of the Shiprock NTMS Quadrangle, New Mexico/Arizona, Including Concentrations of Forty-two Additional Elements," Los Alamos National Laboratory report LA-8002-MS, 1980.

/30/ Morgan, T .L., W. E. George, C. T. Apel, C. J. Martell, S. R. Garcia and C. McInteer, "Uranium Hydrogeochemical and Stream Sediment Reconnaissance of the Dalhart NTMS Quadrangle, New Mexico/Texas/Oklahoma, Including Concentrations of Forty-two Additional Elements," Los Alamos National Laboratory report LA-8008-MS, 1980.

131/ S. L. Bolivar, "Uranium Hydrogeochemical and Stream Sediment Reconnaissance Data Release for the Santa Fe NTMS Quadrangle, New Mexico, Including Concentrations of Forty-two Additional Elements," Los Alamos National Laboratory report LA-8014-MS, 1980.

/32/ C. M. LaDelfe, "Uranium Hydrogeochemical and Stream Sediment Reconnaissance of the Casper NTMS Quadrangle, Wyoming, Including Concentrations of Forty-two Additional Elements," Los Alamos 
National Laboratory report LA-7511MS, 1980.

/33/ Bolivar, S. L. and D. E. Hill, "Uranium Hydrogeochemical and Stream Sediment Reconnaissance of the Casper NTMS Quadrangle, Wyoming, Including Concentrations of Forty-two Additional Elements," Los Alamos National Laboratory report LA-7506-MS, 1979.

/34/ Purson, J. D. and R. G. Warren, "Uranium Hydrogeochemical and Stream Sediment Reconnaissance of the La Junta NTMS Quadrangle, Colorado, Including Concentrations of Forty-three Additional Elements," Los Alamos National Laboratory report LA-7343-MS, 1979.

/35/ S. S. Shannon, "Uranium Hydrogeochemical and Stream Sediment Reconnaissance of the Pueblo NTMS Quadrangle, Colorado, Including Concentrations of Forty-two Additional Elements," Los Alamos National Laboratory report LA-7541-MS and suppl., 1978.

/36/ P. K. Trexler, "Uranium Hydrogeochemical and Stream Sediment Reconnaissance of the Cheyenne
NTMS Quadrangle, Wyoming," Los Alamos National Laboratory report LA-7237-MS, 1978.

137/ D. W. Barr, Los Alamos National Laboratory retired, personal communication.

/38/ Merrill, Jr., G. L., D. W. Efurd, W. A. Myers and K. D. Rosenlof, "A Comment on 'Remote Plutonium Contamination and Total Inventories from Rocky Flats, "' Health Phys., 33, 105, 1977.

/39/ Krey, P. W. and B. T. Krajewski, "Plutonium Isotopic Ratios in Soil Around the Rocky Flats Plant," U. S. Atomic Energy Commission report HASL-249, I-67, 1972.

140/ "Environmental Surveillance at Los Alamos During 1988," Los Alamos National Laboratory report LA11628-ENV, 1989.

141/ Thomas, C. W. and D. E. Robertson, "Radionuclide Concentrations in Reservoirs, Streams and Domestic Waters Near the Rocky Flats Installation," Pacific Northwest Laboratory report PNL-2919, April, 1980. 